\title{
Dynamic Response of a Full-Scale Reinforced Concrete Building Frame Retrofitted with FRP Column Jackets
}

\author{
Jiuk Shin ${ }^{\mathrm{a}}$, David W. Scott ${ }^{\mathrm{a}}$, , Lauren K. Stewart ${ }^{\mathrm{a}}$, Chuang-Sheng Yang ${ }^{\mathrm{a}}$, Timothy R. Wright ${ }^{\mathrm{a}}$, \\ and Reginald DesRoches ${ }^{\mathrm{a}}$ \\ ${ }^{a}$ School of Civil and Environmental Engineering, Georgia Institute of Technology, Atlanta, GA 30332, USA \\ * Corresponding author. E-mail address: dscott@ gatech.edu; Tel.: +1 404894 1485;
}

\begin{abstract}
Many existing reinforced concrete buildings designed in accordance with pre-1971 codes are generally dominated by weak column-strong beam behavior under seismic loading due to inadequate reinforcement detailing. This behavior can lead to premature failure under seismic loads from damage concentrated in the first story of the structure. This paper presents the results of an experimental investigation into the seismic response of a full-scale, two-story non-ductile reinforced concrete frame. The frame was retrofitted with a fiber-reinforced polymer jacketing system on the first story columns to mitigate seismic vulnerability. Shake weight testing was performed to investigate the dynamic performance of the retrofitted building structure in terms of the modal response, inter-story drift, and effectiveness of the fiber-reinforced polymer jacketing system. The results demonstrate that the retrofit scheme helped develop a more uniform story drift distribution, working to counter the soft-story mechanism commonly found in reinforced concrete frames designed during this period.
\end{abstract}


Keywords: Shaker testing; non-ductile reinforced concrete frame; Fiber-reinforced polymer (FRP) jacketing system; Soft-story mechanism; Seismic strengthening

\section{Introduction}

Past seismic events (e.g. the 1989 Loma Prieta earthquake, and the 1994 Northridge earthquake) have demonstrated that many existing reinforced concrete (RC) frame buildings constructed prior to 1971 have a structural vulnerability to seismic loading. This vulnerability can be attributed to inadequate reinforcement detailing in frame columns, including: (1) large spacing of small-diameter transverse reinforcement, leading to poor concrete confinement and inadequate lateral support of longitudinal reinforcing; (2) $90^{\circ}$ L-shaped corner hooks for rectangular column ties, resulting in loss of confinement and longitudinal reinforcement support after concrete cover spalling; and (3) inadequate lap splice lengths, causing low lateral resistance at high bending moment areas [1-9]. Inadequate detailing in combination with a low $\Sigma \mathrm{M}_{\mathrm{c}} / \Sigma \mathrm{M}_{\mathrm{b}}$ ratio (where $\mathrm{M}_{\mathrm{c}}$ and $\mathrm{M}_{\mathrm{b}}$ are the moment capacities of columns and beams in the structure) often results in weak column-strong beam (WCSB) behavior in non-ductile RC frames. This damage or collapse mechanism is concentrated on specific stories when subjected to seismic loads, often resulting in premature failure in the structure [1-6]. In order to prevent the failure of seismically deficient RC columns, a number of column jacketing techniques have been developed using a range of materials and fabrication techniques including steel, fiber reinforced polymer (FRP) wraps, and prefabricated FRP shapes [10-20]. Among the retrofit schemes, the prefabricated FRP jacketing system is expected to have significant advantages related to constructability in terms of quality control and the speed of installation [17, 18]. Thus, a prefabricated FRP jacketing system was selected for this study to retrofit seismically vulnerable columns in a nonductile RC frame. 
To investigate the effectiveness of this retrofit approach, a series of dynamic tests were performed on a full-scale, non-ductile RC frame retrofitted with prefabricated FRP jackets on the first story columns. A hydraulic linear shaker was installed on the roof to generate an excitation in the structure. The dynamic response of the retrofitted test frame was evaluated in terms of natural frequency, inter-story drift, and column and beam rotations. Furthermore, the relative effectiveness of the FRP jacketing system was investigated by comparing the dynamic responses between as-built and retrofitted RC frames.

\section{Previous Work}

\subsection{Column jacketing systems}

Column jacketing systems have been developed to strengthen seismic capacities of existing structures. Priestley et al. $[10,11]$ proposed the use of steel jackets for seismically vulnerable bridge columns and validated the effectiveness of the retrofit through experimental studies. The test results showed that the retrofit of steel jackets enhanced the shear strength of columns and prevented premature failure. However, using steel jackets on RC columns can result in the addition of significant weight, increased construction time, and potential future corrosion issues $[12,13]$. Given the problems associated with the use of steel in these types of applications, FRP jacketing systems have been proposed as an alternative to improve the seismic performance of RC columns. The typical structural behavior for RC columns with and without the FRP jacketing system is illustrated in Fig. 1. As shown in Fig. 1(a), the FRP jacket confines the dilation of concrete columns under axial compression, and provides a radial passive stress $\left(\sigma_{R}\right)$. Consequently, the confinement effect resulting from $\sigma_{R}$ contributes to the enhancement of

concrete compressive strength $\left(f_{\mathrm{cc}}{ }^{\prime}\right)$ and ultimate axial strain $\left(\varepsilon_{\mathrm{cu}}\right)$. Through this confinement 
effect, the seismic response for an RC column retrofitted with the FRP jacketing system can be improved as shown in Fig. 1(b) with additional flexural capacity as well as an increase in stiffness and ductility [21-24]. However, the confinement effect is significantly affected by the cross section shapes of the columns [9, 25-29]. To evaluate the effectiveness of FRP jacketing systems with respect to cross section, Haroun et al. [9] tested circular and rectangular RC columns retrofitted with FRP jacketing systems. The test results showed that the square sections were less effective than their circular counterparts because the rectangular section was not uniformly confined by the FRP jackets and the confinement effect was greatly reduced [25-29]. To maximize the confinement effect, section enlargement from a rectangular or square shape to a circular or elliptical shape was accomplished using FRP jackets with non-shrink grout filling the annular space. ElGawady et al. [30] demonstrated that the application of shape enlargement with circular FRP jackets in the plastic hinge region of rectangular RC columns significantly improved the displacement ductility, energy dissipation and lap-splice capacity of RC columns with deficient lap-splices. A typical retrofit scheme with an enlarged section that is fullyconfined by FRP jackets for RC columns is shown in Fig. 2.

To demonstrate the effectiveness of FRP jacketing systems related to shear failure, flexural failure and lap-splice failure of seismically vulnerable RC columns, Seible et al. [14-16] conducted quasi-static tests for column specimens retrofitted with a variety of FRP jackets. The test results showed that FRP jacketing systems could be effective to prevent certain failure modes in non-ductile RC columns. Based on these experimental studies, a retrofit design process of FRP jacketing systems was proposed and validated by Seible et al. [31, 32]. Xiao et al. [17, 18] applied prefabricated FRP jackets to existing circular RC columns to enhance the shear strength and lap-splice capacity of non-ductile RC bridge columns designed according to pre- 
1970s codes. The test results indicated that the prefabricated FRP jacket completely prevented shear failure and contributed to stable ductile behavior without any significant degradation in stiffness and strength. Additionally, the use of prefabricated FRP jacket delayed the premature lap-splice failure. A number of studies of non-ductile RC building columns were conducted to investigate the effectiveness of FRP jacketing systems for the most common possible failure modes (i.e. axial-flexural failure [7], lap-splice failure [8] and shear failure [33]). In each case, the jacket design was based on the procedure proposed by Seible et al, [31, 32]. Through an extensive experimental investigation, the FRP jackets provided a sufficient confinement pressure to improve the flexural, shear and lap-splice capacities of the RC columns as well as increase the longitudinal reinforcement buckling resistance.

\subsection{Dynamic testing of $R C$ frames}

To investigate the seismic response and modal properties for RC building structures, a variety of shake table tests [e.g. 2, 5, 34-36] have been performed to simulate seismic loading. However, the size, weight and strength of test specimens were necessarily limited in these types of experiments due to the capacities of available shake table equipment [37-39]. Consequently, previous experimental studies typically employed reduced scale specimens in their testing programs. In addition, to measure the modal properties of real structures and calibrate analytical models, prior researchers conducted field testing of full-scale RC structures subjected to ambient and low-level forced vibrations $[40,41]$. In order to overcome those limitations, the National Science Foundation George E. Brown Jr. Network for Earthquake Engineering Simulation (NEES) established the University of California, Los Angeles NEES Equipment Site, which developed a mobile shaker system [42] for lateral excitation simulating earthquake motions on full scale structures. This system has been used previously in forced vibration testing for a four- 
story RC building to calibrate analytical models based on the experimental results and to better understand the dynamic responses of the real structure [37-39].

\subsection{Soft-story mechanism}

Non-ductile RC building structures that exhibit WCSB behavior are typically dominated by the soft-story mechanism. The soft-story mechanism can lead to severe damage in the lowerstories, whereas the upper-stories remain undamaged. In other words, the drift of the structure can be more prevalent on the lower-stories (i.e. non-uniform story drift distribution), with high column hinge rotation [1-6]. Current design codes require a strong column-weak beam (SCWB) system for RC moment resisting frames to ensure ductile behavior of the structure [4-6]. Such building structures can develop a beam sidesway mechanism or a mixed sidesway mechanism. These mechanisms tend to distribute plastic hinges more uniformly in beams for approximately $2 / 3$ the height of the structure compared to a WCSB system - the damage is not concentrated on the columns in lower-stories. Thus, building structures designed according to current codes can generate a more uniform story drift distribution and lower column hinge rotation in the lowerstories than non-ductile RC building structures when subjected to seismic loads.

\section{Experimental Program}

\subsection{Test setup and specimen details}

To perform full-scale dynamic experiments, four identical two-story two-bay non-ductile RC frames were constructed as shown in Fig. 3(a). This work presents results from tests on two of the constructed frames. One test frame was tested in the as-built condition (hereafter referred to as the "as-built test frame.") Another test frame was retrofitted with FRP jackets on the first story columns prior to testing (see Fig. 3(b)). To estimate the effectiveness of the FRP jacketing 
system, the retrofitted test frame was compared to the as-built test frame. The material properties of the frame are summarized in Table 1, where the concrete strengths are average compressive values and the steel strengths are yield strengths. In addition, the strength of the FRP jacket is given as the tensile stress corresponding to the ultimate strain $(0.011)$ in the material at rupture. The material properties given in Table 1 were determined in accordance with relevant ASTM standards [43-46]. Fig. 4 shows reinforcing details for the test frame. Fig. 5 provides a schematic illustration of the test setup and test frame details - section details for columns and beams (see Fig. 5(b)), along with interior and exterior beam column joints (see Figs. 5(c) and (d)). To simulate gravity loading, steel rails weighing approximately $8.08 \mathrm{kN} / \mathrm{m}$ and $6.86 \mathrm{kN} / \mathrm{m}\left(w_{1}\right.$ and $w_{2}$ in Fig. 5(a)) were distributed over the first and second floors, respectively. As shown in Fig. 5(a), two shakers were utilized to perform the full-scale dynamic experiment. In this study, a $334 \mathrm{kN}$ hydraulic linear shaker was anchored to the middle of the second floor to apply the seismic and sine pulse vibrations to the roof. In addition, a portable eccentric mass shaker (EMS) with a maximum capacity of $110.7 \mathrm{kN}-\mathrm{mm}$ was fixed on the first floor (between B13 and B14 in Fig. 5(a)) to estimate modal properties of the test frames. The hydraulic linear shaker and portable EMS are shown in Fig. 6. The base plate of the linear shaker (see Fig. 6(a)) was rigidly connected to the second floor. Through the movement of the shaker mass block (i.e. seismic and sine pulse vibrations), the reaction force was transferred into the second floor. Thus, unlike a traditional test setup, there were no reaction walls and actuators employed. The as-built RC frame was designed for gravity loads only in accordance with the 1963 edition of the American Concrete Institute (ACI) design code [47]. The first story columns for both the RC frames were built with a lap-splice length of $610 \mathrm{~mm}$ at the column base and non-ductile transverse reinforcement detailing (spacing @ $305 \mathrm{~mm}$ and $90^{\circ}$ column ties). These 
configurations are often found in building structures constructed in the United States prior to the 1970s. To compensate for the non-ductile RC columns in the first story, prefabricated FRP jackets were installed on the three columns in the first story in the retrofitted frame. Unlike the first story columns, the second story columns were designed with a relatively narrow transverse reinforcement spacing $(178 \mathrm{~mm})$ and longer lap-splice lengths $(914 \mathrm{~mm})$. Ties with a specified angle of $135^{\circ}$ were used in the second story center column (between C32 and C42 in Fig. 5(a)). This was intended to transfer the vibration loads from the second story to the first story and avoid an unexpected failure during the dynamic testing. More detailed information on the design of the frame and test setup can be found in [48].

Fig. 7 shows the details of an RC column in the as-built frame (Fig. 7(a)) and an FRP jacketed column in the retrofitted frame (Fig. 7(b)). The present work followed the retrofit design process proposed by Seible et al. [31,32]. The first step in the design process was to estimate the lateral resisting capacity, ductility, shear strength, and lap-splice failure for the asbuilt column details using a sectional analysis. A moment-curvature relation of the as-built column was gained from the sectional analysis and the ductility of the as-built column $\left(\mu_{0}\right)$ was calculated as the ratio of ultimate curvature to yielding curvature $\left(\mu_{0}=2.25\right)$. After performing the sectional analysis of the as-built column, a target ductility $\left(\mu_{\text {target }}=4.50\right)$ twice that of $\mu_{0}$ was established. The confined concrete compressive strength was conservatively assumed as 1.5 times unconfined concrete strength $\left(f_{\mathrm{cc}}{ }^{\prime}=1.5 f_{\mathrm{c}}{ }^{\prime} \approx 47.1 \mathrm{MPa}\right)$ based on work done by previous researchers [49]. Under these assumptions, the required number of FRP plies needed to prevent the three possible failure modes was determined. Detailed examples of the FRP retrofit design process can be found in [32]. This resulted in the jacketing system installation shown in Fig. 7(b) with a two-ply FRP jacket (1.32 $\mathrm{mm}$ in thickness) and one-ply FRP jacket $(0.66 \mathrm{~mm}$ in 
thickness) in the $l_{1}$ and $l_{2}$ regions, respectively. The FRP retrofitted columns were designed to reduce the damage levels in the as-built columns - from the near collapse (or collapse prevention (CP)) level in the as-built columns to the life safety (LS) level in the FRP retrofitted columns. The hinge rotation at the $\mathrm{CP}$ limit for the as-built columns based on a sectional analysis is $\theta_{\mathrm{CP}}=$ 0.029 radians. A similar analysis on the FRP retrofitted columns results in an expected hinge rotation at the CP limit of $\theta_{\mathrm{CP}}=0.065$ radians. Previous studies [7-9] have demonstrated that the typical failure mode for the FRP jacketed columns was rupture on the tension face of the column base. As such, the CP damage limit was assumed to coincide with rupture in the FRP jacket. Based on the sectional analysis of the retrofitted column, the FRP jackets increased flexural stiffness for the retrofitted column by approximately $88 \%$ compared to the as-built column, and increased the lateral load resisting capacity by approximately $68 \%$.

Federal Emergency Management Agency (FEMA) 547 [50] provides a construction guideline for column jacketing systems. In this guideline, the surface of the existing concrete must be appropriately roughened to ensure sufficient bond between new and existing materials. However, FEMA 547 does not give specific criteria for the substrate concrete surface profile (CSP). As such, recommendations given by the International Concrete Repair Institute (ICRI) [51] were followed. ICRI recommends a CSP of 7 to 9 to ensure adequate bond between the substrate concrete and the retrofit material; this was accomplished using hand-held concrete breakers. Next, prefabricated FRP sheets were formed into a circular shape around the existing square columns; the circular shape was permanently formed using an epoxy resin. The annular space between the jacket and column was then filled with a non-shrink grout. Detailed construction installation procedures for the commercially available FRP retrofit system can be found in [52]. As recommended in FEMA 547, gaps of approximately $13 \mathrm{~mm}$ were left at the 
column top and bottom to inhibit the interaction between the FRP jacket and the adjacent elements (e.g. slab, beam and foundation).

\subsection{Loading sequences and instrumentation plan}

The hydraulic linear shaker on the roof imparted two different phases of excitations to the test frames: seismic vibration and sinusoidal pulses. Each input excitation corresponded to a target displacement of the linear shaker. Table 2 presents the loading sequences of as-built and retrofitted test frames for two different excitation phases with specified target displacements: 1940 El Centro (EC) earthquake (Phase 1) and single or double sinusoidal pulse (SP) vibration (Phase 2). During Phase 1 (EC 1 to EC 8), the target displacement of the linear shaker increased from $25.4 \mathrm{~mm}$ to $203 \mathrm{~mm}$. During SP 4 and SP 8 in Phase 2, the shaker generated excitations with a single sinusoidal pulse, while SP 12 to SP 20 generated vibrations with double sinusoidal pulses. The linear shaker displacement increased from $102 \mathrm{~mm}$ to $508 \mathrm{~mm}$. The maximum velocities of seismic and sine vibration loads were 1.51 and $1.83 \mathrm{~m} / \mathrm{sec}$, respectively. In this study, the seismic loading sequences (Phase 1) were scaled from the time history of the $1940 \mathrm{El}$ Centro Earthquake [53]. The El Centro record was selected because it has been used extensively with the linear shaker employed in this research program [38]. Sine pulse loading sequences were scaled in accordance with the increase in the target displacement of the hydraulic linear shaker.

The dynamic responses of the full-scale test frames were recorded using 87 sensors (38 LVDTs, 6 string potentiometers, 34 uniaxial accelerometers and 9 triaxial accelerometers) installed throughout the frames. The accelerometers were installed to estimate modal properties. The string potentiometers were mounted on the bottom of the slab to measure a global displacement at each story level. As an example, the sensor configuration at the C22 and C32 
beam-column joint (see Fig. 5(a)) is shown in Fig. 8. To measure the hinge rotations of the left and right beams at the expected plastic hinge locations, four LVDTs were horizontally installed on the top and bottom surfaces of the beam or slabs. Four vertical LVDTs were installed at two opposite sides of the columns to monitor the hinge rotations of the columns.

\section{Experimental Results}

\subsection{Modal responses and damage observation of retrofitted frame}

To obtain the natural frequencies of the retrofitted frame, the EMS shaker installed on the first floor was used to produce ambient vibrations before and after the top excitations generated by the hydraulic linear shaker on the roof. The measured natural frequencies of the first and second modes for the retrofitted frame for each of the ten loading sequences are shown in Fig. 9. The initial natural frequencies (i.e. before the first excitation) for the first and second modes were $1.88 \mathrm{~Hz}$ and $4.70 \mathrm{~Hz}$, respectively. In general, the natural frequencies gradually decreased with the progression of the loading sequences. At the end of Phase 1, no visible damage was observed in the structure and the natural frequencies decreased by about $8 \%$. During the application of sinusoidal pulses (Phase 2), visible damage was observed after SP 8 as shown in Fig. 10. An approximately $2 \mathrm{~mm}$ joint crack in the slab immediately adjacent to the column was observed (see Fig. 10), and longitudinal reinforcement at the column base was exposed due to concrete cover spalling. This damage resulted in a frequency reduction compared to initial measured values of $12.8 \%$ and $23.4 \%$ for the first and second modes, respectively. Following the final loading sequence (SP20), the measured natural frequencies in the retrofitted frame decreased by $20.2 \%$ and $36.2 \%$ compared to the initial measured values.

\subsection{Dynamic response of retrofitted frame}


Story displacements were recorded using string potentiometers located at the corners of each story. The peak inter-story drift ratios are shown in Fig. 11 under selected loading sequences - Phase 1 (EC 1 to EC 8) in Fig. 11(a) and Phase 2 (SP 4 to SP 20) in Fig. 11(b). For simplicity, only representative test results are shown in Fig. 11. In this study, the damage levels of the retrofitted frame with respect to the inter-story drift ratio (IDR) were defined according to the three limit states of RC frames specified in FEMA 356 [54]. The drift limits with respect to performance levels are summarized in Table 3. In this study, since loading gradually increased until the shaker capacity was reached and the building target performance was not specified in the FRP retrofit design process used, the corresponding seismic hazard levels for the test frames were not identified. However, the performance levels (IO, LS and CP) from FEMA 356 were utilized in this study to provide an indication of the damage incurred in the test frames under each loading sequence. As shown in Fig. 11, the peak inter-story drift ratio increased as the shaker's target displacement increased. During Phase 1 (Fig. 11(a)), the peak inter-story drift ratio was within the immediate occupancy (IO) level without visible damage. However, after the visible damage was observed during SP 8, the peak inter-story drift ratio of the first story in the retrofitted frame reached the life safety (LS) level, as shown in Fig. 11(b). The change in the limit state from IO to LS was attributed to a joint crack in the slab immediately adjacent to the C13 column, as shown in Fig. 10, and concrete cover spalling in the C13 column base. In the final loading sequence (SP 20), the peak inter-story drift ratios on both stories were within the LS level, but no additional visible damage was observed on the first and second stories.

The maximum hinge rotations of column and beam components are shown in Figs. 12(a) and (b) under selected loading sequences. The limit states for rotation of beams and columns, shown in Fig. 12, were adopted from American Society of Civil Engineers (ASCE) 41-13 [55]. 
The rotational limits with respect to the performance levels are summarized in Table 3 . This study employed these rotational limits to identify the damage sequence of the retrofitted frame under the loading sequences. The rotational demands of the beams and columns in the retrofitted frame reveal that the top and bottom of the first story columns reached the LS level first and were the most vulnerable components, followed by the second story column bases and the first story beam portions near the exterior joints.

\subsection{Effectiveness of FRP jacketing system}

Prior to dynamic testing of the RC frame retrofitted with the FRP jacketing system, an asbuilt RC frame without any retrofits was tested in a similar fashion to provide a basis for comparison. The dynamic responses obtained from the as-built frame were compared to those of the retrofitted frame under selected loading sequences as shown in Table 2. The drift reduction ratios for the first story, where the FRP jacketing system was installed, are shown in Fig. 13. The drift reduction ratio is defined in Eq. 1 where $\Delta_{\text {As-built }}$ is the peak inter-story drift of the asbuilt frame, and $\Delta_{R \text { etrofitted }}$ is the peak inter-story drift of the retrofitted frame.

$$
\text { Drift reduction ratio }(\%)=\left(\Delta_{\text {As-built }}-\Delta_{\text {Retrofitted }}\right) / \Delta_{\text {As-built }} \times 100
$$

A positive value for the drift reduction ratio represents a reduction in the inter-story drift. As shown in Fig. 13, the FRP jackets reduced the inter-story drift ratios in the first story for all loading sequences applied in Phase 1. This reduction in inter-story drift ratio can be attributed to the increase in stiffness of the frame system by means of the installation of the FRP jackets and the section enlargement in the first story columns, compared to the as-built test frame.

The effectiveness of the FRP jacketing system can also be demonstrated by comparing the column hinge rotations in the first story between the as-built and retrofitted frames. To 
properly compare the column hinge rotations between frames, the rotation values must be normalized by dividing the rotations by the corresponding measurement geometry for the LVDTs used - the change in section due to the column jackets in the retrofitted structure preclude a one-to-one comparison of rotations between the frames. The rotation reduction ratios on the top and bottom of the first story columns are given in Fig. 14. The rotation reduction ratio of a column was calculated using Eq. 2 where $\theta_{\text {As-built }}$ is the maximum normalized column rotation of the as-built frame, and $\theta_{\text {Retrofited }}$ is the maximum normalized column rotation of the retrofitted frame.

$$
\text { Rotation reduction ratio }(\%)=\left(\theta_{\text {As-built }}-\theta_{\text {Retrofitted }}\right) / \theta_{\text {As-built }} \times 100
$$

A positive value represents the reduction in the column rotation induced by the FRP jacketing system. As shown in Fig. 14, the FRP jacketing system reduced the measured column rotations at the bottom and the top of the first story columns. The maximum reductions for the bottom and top of the first story columns were approximately $60 \%$ and $40 \%$, respectively. Although the retrofitted frame experienced a stiffness reduction due to the damage observed after loading sequence SP 8, the FRP jacketing system in the first story still reduced the first story column rotations by more than $40 \%$. A similar reduction can also be observed in the larger excitation of loading sequence SP 12. As observed from the full-scale experimental results under the SP12 external vibration level, the demands of the first story as-built columns were close to the CP limit - the largest measured rotation was 0.024 radians, compared to the as-built column $\mathrm{CP}$ limit of 0.029 radians. The demands of the first story FRP retrofitted columns - measured as 0.018 radians - were significantly less than the expected CP limit. Thus, the design expectation (reducing damage from the $\mathrm{CP}$ level in the as-built columns to the LS level) was met using the 
FRP retrofitted columns. Additionally, no failure occurred in the FRP jacket when the retrofitted frame was under the ultimate loading sequence - under SP20, the largest rotation measured in the first story FRP retrofitted columns was 0.027 radians, less than the FRP column CP limit of 0.065 radians.

To quantify the uniformity of inter-story drifts over the entire structure, the drift concentration factors $(D C F \mathrm{~s})$ for the as-built and retrofitted frames were evaluated. The $D C F$ for a story is defined as the ratio of the peak inter-story drift ratio for the considered story to the roof drift ratio $[56,57]$ as given by Eq. 3 where $D C F_{i}$ is the $D C F$ in the $\mathrm{i}^{\text {th }}$ story, $\Delta_{i}$ is the $\mathrm{i}^{\text {th }}$ inter-story drift, $\delta_{\text {roof }}$ is the roof story displacement, $h_{i}$ is the $\mathrm{i}^{\text {th }}$ story height, and $H$ is the entire height of the structure.

$$
D C F_{i}=\left(\Delta_{i} / h_{i}\right) /\left(\delta_{\text {roof }} / H\right)
$$

Based on this definition, if the $D C F$ values for all stories are equal to 1.00 , the structure will develop a uniform story drift distribution as shown in Fig. 15(a). However, if the structure is dominated by the soft-story mechanism as shown in Fig. 15(b), specific stories with concentrated drift will have $D C F$ s larger than 1.0 and values for stories with less damage will be closer to zero. The $D C F \mathrm{~s}$ in the first and second stories $\left(D C F_{1}\right.$ and $\left.D C F_{2}\right)$ for the as-built and retrofitted frames are shown in Fig. 16. For the as-built frame, $D C F_{1}$ ranges between 1.5 and 1.7, and $D C F_{2}$ varies from 0.3 to 0.5 . The $D C F$ s of the as-built frame shows evidence of a potential soft story mechanism. However, the FRP jacketing system reduced $D C F_{1}$ and simultaneously increased $D C F_{2}$, leaving both the $D C F_{1}$ and $D C F_{2}$ values closer to 1.0 . It is reasonable to infer that the FRP jacketing system installed in the first story helped generate a more uniform story drift distribution for the frame, mitigating the drift or damage concentration in the first story. 


\section{Conclusions}

The present work investigated the dynamic response of a two-story two-bay non-ductile RC frame retrofitted with an FRP jacketing system on columns in the first story. The effectiveness of the FRP jacketing system in improving the dynamic performance of the frame was evaluated using an experimental study. Based on this investigation, the following conclusions can be drawn:

1) During the Phase 1 loading sequence, as the loads were increased, the natural frequencies of the retrofitted frame slightly decreased. No visible damage was observed during this stage of the loading, but it is assumed that minor damage was occurring. Additionally, the peak inter-story drift ratios of the retrofitted frame were within the Immediate Occupancy (IO) level (inter-story drift ratio $\leq 1.0 \%$ defined in FEMA 356 [54]). During the Phase 2 loading sequences (sinusoidal pulse excitation), the peak inter-story drift ratio of the first story reached the drift Life Safety (LS) level after the concrete cracking (see Fig. 10) occurred in the slab immediately adjacent to the first story column base and cover spalling. Consistent with the drift LS level, the maximum hinge rotation of the first story columns reached the rotation LS level. Following the loading sequence where visible damage was observed in the structure, the second story columns reached the LS level. After further loading sequences were applied to the structure, the beam rotations near the two exterior joints in the first story reached the LS level for rotation. This damage sequence indicates that the most 
vulnerable component in the structural system is the first story columns, followed by the second story column base, and then the beam elements near the exterior joints.

2) By comparing the dynamic responses between the as-built and retrofitted frames, the installation of the FRP jacketing system in the first story was shown effective in reducing both story drift (maximum drift reduction $\approx 22 \%$ ) and column rotations in the first story (maximum rotation reduction $\approx 60 \%$ ). This improvement in performance in the retrofitted frame may be attributed to an increase in concrete confinement in the first story columns which enhanced their lateral strength, stiffness, and ductility compared to the as-built configuration.

3) The installation of the FRP jacketing system on the first story columns brought the drift concentration factors $(D C F \mathrm{~s})$ for the retrofitted frame closer to 1.0, indicating that the retrofitted frame has a more uniform drift distribution than the as-built frame, which is a better scenario to avoid damage due to a soft story mechanism. This indicates that the retrofit scheme employed in this study can help mitigate the softstory mechanism commonly existing in RC frames designed according to the pre1971 codes for structural concrete.

\section{Acknowledgments}

This work was supported primarily by the George E. Brown, Jr. Network for Earthquake Engineering Simulation (NEES) Program of the National Science Foundation under Award 
Number CMMI-1041607. This support is gratefully acknowledged. Any opinions, findings, conclusions or recommendations are those of the authors and do not necessarily reflect the views of other organizations.

\section{References}

[1] Aycardi LE, Mander JB, Reinhorn AM. Seismic resistance of reinforced concrete frame structures designed only for gravity loads: experimental performance of subassemblages. ACI Structural Journal 1994; 91(5):552-63.

[2] Bracci JM, Reinhom AM, Mander JB. Seismic resistance of reinforced concrete frame structures designed for gravity loads: performance of structural system. ACI Structural Journal 1995; 92(5): 597-609.

[3] Beres A, Pessiki S, White R, Gergely P. Implications of experiments on the seismic behavior of gravity load designed RC beam-to-column connections. Earthquake Spectra 1996; 12:185-98.

[4] Priestley MJN. Displacement-based seismic assessment of reinforced concrete buildings. J Earthquake Eng 1997; 1(1):157-92.

[5] El-Attar AG, White RN, Gergely P. Behavior of gravity load designed reinforced concrete buildings subjected to earthquake. ACI Structural Journal 1997; 94(2): 133-45.

[6] Hakuto S; Park R; and Tanaka H. Seismic Load Tests on Interior and Exterior BeamColumn Joints with Substandard Reinforcing Details. ACI Structural Journal Jan.-Feb. 2000; 97(1): 11-25.

[7] Sause R, Harries KA, Walkup SL, Pessiki S, Ricles JM. Flexural behavior of concrete columns retrofitted with carbon fiber reinforced polymer jackets. ACI Structural Journal 2004;101(5):708-16.

[8] Harries K, Ricles J, Pissiki S, Sause R. Seismic retrofit of lap splices in nonductile columns using CFRP jackets. ACI Struct. J. 2006; 103(6): 226-236.

[9] Haroun MA, Mossalam AS, Feng Q, Elsanadedy HM. Experimental investigation of seismic repair and retrofit of bridge columns by composite jackets. Journal of Reinforced Plastics and Composites 2003; 22(14): 1243-1268.

[10]Priestley MJN, Seible F, Xiao Y, Verma R. Steel jacket retrofitting of reinforced concrete bridge columns for enhanced shear strength-Part 1: Theoretical considerations and test design. ACI Structural Journal 1994; 91(4):394-405. 
[11]Priestley MJN, Seible F, Xiao Y, Verma R. Steel jacket retrofitting of reinforced concrete bridge columns for enhanced shear strength-Part 2: Test results and comparison with theory. ACI Structural Journal 1994; 91(5):537-551.

[12]Lan YM, Sotelino ED, Chen WF. State-of-the-art review of highway bridge columns retrofitted with FRP jackets. Department Report CE-STR-98-5; School of Civil Engineering Purdue University; West Lafayette (IN); 1998.

[13]Teng M-H, Sotelino ED, Chen W-F. Performance evaluation of reinforced concrete bridge columns wrapped with fiber reinforced polymers. ASCE J Compos Constr 2003; 7(2): 83-92.

[14]Seible F, Priestley MJN, Innamorato D, Weeks J, Policelli F. Carbon fiber jacket retrofit test of circular shear bridge column. CRC-2. Advanced Composites Technology Transfer Consortium Rep. No. ACTT-94/02, University of California, San Diego, La Jolla, California; 1994.

[15]Seible F; Hegemier GA; Priestly MJN; Ho F; Inmamorato D. Rectangular carbon jacket retrofit of flexural column with 5\% continuous reinforcement. Advanced Composites Technology Transfer Consortium Report No. ACTT-95/03, University of California, San Diego, La Jolla, California; 1995.

[16]Seible F, Hegemier GA, Priestley MJN, Innamorato D, Ho F. Carbon fiber jacket retrofit test of circular flexural columns with lap spliced reinforcement. Advanced Composites Technology Transfer Consortium Report No. ACTT-95/04, University of California, San Diego, La Jolla, California; 1995.

[17]Xiao Y, Ma R. Seismic retrofit of RC circular columns using prefabricated composite jacketing. Journal of Structural Engineering 1997; 123(10): 1356-64.

[18]Xiao Y, Wu H, and Martin GR. Prefabricated composite jacketing of RC columns for enhanced shear strength. J. Struct. Eng. 1999; 125(3): 255-64.

[19]Pantelides CP, Gergely I, Reaveley LD, Volnyy VA. Retrofit of RC bridge pier with CFRP advanced composites. Journal of Structural Engineering, ASCE 1999;125(10):1094-9.

[20]Pantelides CP, Duffin JB, Reaveley LD. Seismic strengthening of reinforced concrete multicolumn bridge piers. Earthquake Spectra 2007;23(3):635-64.

[21]Mander JB, Priestley MJN, Park R. Observed stress-strain behavior of confined concrete. ASCE J Struct Eng 1988; 114(8):1827-48

[22]Saatcioglu M, Razvi SR. Strength and ductility of confined concrete. J Struct Eng, ASCE 1992; 118(6):1590-607. 
[23]Xiao Y, Wu H. Compressive behavior of concrete confined by carbon fiber composite jackets. Journal of Material for Civil Engineering 2000; 12(2): 139-46

[24]Fam AZ, Rizkalla SH. Confinement model for axially loaded concrete confined by circular fiber-reinforced polymer tubes. ACI Structural Journal 2001; 98(4):451-61.

[25]Al-Salloum YA. Influence of edge sharpness on the strength of square concrete columns confined with FRP composite laminates. Composites Part B: Engineering 2007;38: 64050 .

[26]Wang LM, Wu YF. Effect of corner radius on the performance of CFRP-confined square concrete columns: Test. Eng Struct 2008; 30(2):493-505.

[27]Yan Z, Pantelides CP, Reaveley LD. Fiber reinforced polymer jacketed and shape modified compression members: I-experimental behavior. ACI Structural Journal 2006; 103(6): 885-93.

[28]Yan Z, Pantelides CP. Fiber reinforced polymer jacketed and shape modified compression members: II-model. ACI Structural Journal 2006; 103(6), 894-903.

[29]Yan Z, Pantelides CP. Concrete column shape modification with FRP shells and expansive cement concrete. Constr Build Mater 2011; 25(1):396-405.

[30]ElGawady M, Endeshaw M, McLean D, Sack R. Retrofitting of rectangular columns with deficient lap splices. J Compos Constr 2010; 14(1): 22-35.

[31]Seible F, Priestley MJN, Innamorato D. Earthquake Retrofit of Bridge Columns with Continuous Carbon Fiber Jackets, Volume II, Design Guidelines. Rep. No. ACTT-95/08. San Diego (CA): University of California, San Diego, La Jolla; 1995.

[32] Seible F, Priestley MJN, Hegemier GA, Innamorato D. Seismic retrofit of RC columns with continuous carbon fiber jackets. Journal of Composites for Construction 1997; 1(2):52-62.

[33]Patel S. Rehabilitation of non-ductile reinforced concrete building columns against brittle shear failure using fiber reinforced polymer jackets. MSc thesis, Lehigh University, Bethlehem (PA); 2000.

[34]Di Ludovico M, Manfredi G, Mola E, Negro P, Prota A. Seismic behavior of a full-scale RC structure retrofitted using GFRP laminates. J Struct Eng 2008; 135(5): 810-21.

[35] Garcia R, Hajirasouliha I, Pilakoutas K. Seismic behavior of deficient RC frames strengthened with CFRP composites. Eng Struct 2010; 32(10): 3075-85.

[36]Koutromanos I, Kyriakides M, Stavridis A, Billington S, Shing P. Shake-table tests of a 3-story masonry-infilled RC frame retrofitted with composite materials. J. Struct. Eng. 2013 SPECIAL ISSUE: NEES 2: Advances in Earthquake Engineering; 139: 1340-51. 
[37] Whang DH, Kang SW, Wallace JW, Stewart JP, Yu E, Lei Y. Integration of NEES grid into the nees@UCLA field testing site. In: Proc 13th World conference on earthquake engineering, Vancouver, BC, Canada, August 1-6 2004. Paper No. 0486.

[38] Yu E, Whang DH, Conte JP, Stewart JP, Wallace JW. Forced vibration testing of buildings using the linear shaker seismic simulation (LSSS) testing method. Earthquake Engng. Struct. Dyn. 2005; 34 (1): 737-761.

[39] Yu E, Skolnik D, Whang D, Wallace JW. Forced vibration testing of a four story RC building utilizing the nees@UCLA mobile field laboratory. Earthquake Spectra 2008; 24: 969-95.

[40] Hudson DE. A comparison of theoretical and experimental determination of building responses to earthquakes. In: Proc 2nd World conference on earthquake engineering, Japan; 1960. 1105-1119

[41] Galambos T, Mayes R. Lessons from dynamic tests of an eleven story building, Engng Struct. 1979; 1: 264-273.

[42] NEES@UCLA. Network for earthquake engineering simulation at the University of California, Los Angeles. Los Angeles (CA): University of California, Los Angeles; 2015. $<$ http://nees.ucla.edu/>

[43] ASTM. Standard test method for compressive strength of cylindrical concrete specimens. ASTM C39 Philadelphia, PA, 2015

[44] ASTM. Standard specification for deformed and plain billet steel bars for concrete Reinforcement. ASTM A615 Philadelphia, PA, 2015

[45] ASTM. Standard test method for compressive strength of hydraulic cement mortars. ASTM C109 Philadelphia, PA, 2013

[46] ASTM. Standard test method for tensile properties of polymer matrix composite materials. ASTM D3039 Philadelphia, PA, 2014

[47] ACI. Building code requirements for reinforced concrete. ACI 318-63. Detroit(MI); 1963

[48]Wright TR. Full-scale seismic testing of a reinforced concrete moment frame using mobile shakers. PhD thesis, Georgia Institute of Technology, Atlanta (GA); 2015.

[49] Ma R, Xiao Y, Li KN. Full-scale testing of a parking structure column retrofitted with carbon fiber reinforced composites. J Construct Building Mater 2000; 14(2): 63-71.

[50] FEMA. Techniques for the seismic rehabilitation of existing buildings. Rep. No. FEMA 547. Washington (DC, USA): Federal Emergency Management Agency; 2006. 
[51] ICRI. Guideline for the preparation of concrete surfaces for repair using hydrodemolition methods. Technical Guideline No. 310.3R-2014. Rosemont (IL); 2014.

[52]Ehsani M, Tipnis A. Miami building first to benefit from innovative pile jacket. Concrete Repair Bulletin July/August 2011; 16-18.

[53]Pacific Earthquake Engineering Research Center. PEER Ground Motion Database. University of California, Berkeley. < http://peer.berkeley.edu/smcat>

[54] FEMA. Pre-standard and commentary for the seismic rehabilitation of buildings, prepared by ASCE. Rep. No. FEMA 356. Washington (DC, USA): Federal Emergency Management Agency; 2000.

[55] ASCE. Seismic Evaluation and Retrofit of Existing Buildings, ASCE/SEI 41-13, American Society of Civil Engineers, 2014.

[56] Ji X, Kato M, Wang T, Hitaka T, Nakashima M. Effect of gravity columns on mitigation of drift concentration for braced frames. J Constr Steel Res 2009; 65:2148-56.

[57] Qu Z, Ye L, Wada A. Seismic damage mechanism control of RC ductile frames from a stiffness point of view. In: Proc 8th international conference on urban earthquake engineering, Tokyo, Japan; 2011. 


\section{Figure Captions}

Fig. 1. Typical behavior of RC columns with and without FRP jacketing system: (a) Axial stress-strain response; (b) Moment-curvature response.

Fig. 2. Typical FRP jacketing retrofit for RC column.

Fig. 3. Full-scale, 2-story 2-bay non-ductile RC test frames: (a) Four identical full-scale test frames; (b) FRP jacketed column in retrofitted test frame.

Fig. 4. Reinforcing details for test frame (unit: $\mathrm{mm}$ )

Fig. 5. Test frame details (unit: $\mathrm{mm}$ ): (a) Retrofitted test frame; (b) Section details; (c) Interior beam-column joint at C22 and C32; (d) exterior beam column joint at C21 and C31.

Fig. 6. Shakers: (a) Hydraulic linear shaker; (b) Portable eccentric mass shaker

Fig. 7. RC column details before and after installation of FRP jacketing system (unit: $\mathrm{mm}$ ): (a) As-built column; (b) Retrofitted column.

Fig. 8. Sensor configuration at C22 and C32 (see Fig. 5(a), unit: mm).

Fig. 9. Natural frequencies of retrofitted test frame.

Fig. 10. Damage observed near the column base (C13 in Fig. 5(a)) after SP 8.

Fig. 11. Peak inter-story drift ratio for selected loading sequences: (a) Phase 1 (El Centro earthquake); (b) Phase 2 (sinusoidal pulse vibration).

Fig. 12. Maximum hinge rotations of column and beam for selected loading sequences: (a) Column hinge rotations; (b) Beam hinge rotations.

Fig. 13. Reduction of drift in the first story due to retrofit scheme.

Fig. 14. Reduction of column rotations in the first story due to retrofit scheme.

Fig. 15. Schematic diagrams for drift distributions: (a) idealized uniform story drift distribution, and (b) soft story mechanism, using drift concentration factors (DCFs).

Fig. 16. Drift concentration factors (DCFs) for as-built and retrofitted test frames. 
Table 1. Summary of material properties.

\begin{tabular}{lll}
\hline Material type & Location/rebar type & Strength $(\mathrm{MPa})$ \\
\hline \multirow{3}{*}{ Concrete } & First story column & 31.4 \\
& First story beam/slab & 26.5 \\
& Second story column & 30.3 \\
& Second story beam/slab & 23.5 \\
\hline \multirow{3}{*}{ Steel } & $\phi 10$ rebar & 520 \\
& $\phi 19$ rebar & 445 \\
FRP & $\phi 25$ rebar & 541 \\
\hline Grout & First story column & 1080 \\
\hline
\end{tabular}


Table 2. Summary of loading sequences.

\begin{tabular}{|c|c|c|c|c|}
\hline \multirow{2}{*}{ Phase } & \multicolumn{2}{|c|}{ Loading sequences } & \multirow{2}{*}{ Vibration type } & \multirow{2}{*}{$\begin{array}{l}\text { Shaker } \\
\text { displacement }\end{array}$} \\
\hline & $\begin{array}{l}\text { As-built } \\
\text { test frame }\end{array}$ & $\begin{array}{l}\text { Retrofitted } \\
\text { test frame }\end{array}$ & & \\
\hline \multirow{5}{*}{ Phase 1} & EC 1 & EC 1 & \multirow{5}{*}{$\begin{array}{l}1940 \text { El Centro } \\
\text { earthquake }\end{array}$} & $25.4 \mathrm{~mm}(1 \mathrm{in})$ \\
\hline & EC 2 & EC 2 & & $50.8 \mathrm{~mm}(2 \mathrm{in})$ \\
\hline & EC 4 & EC 4 & & $101.6 \mathrm{~mm}(4 \mathrm{in})$ \\
\hline & EC 6 & EC 6 & & $152.4 \mathrm{~mm}(6 \mathrm{in})$ \\
\hline & EC 8 & EC 8 & & $203.2 \mathrm{~mm}$ (8 in) \\
\hline \multirow{5}{*}{ Phase 2} & SP 4 & SP 4 & \multirow{2}{*}{ Single sinusoidal pulse } & $101.6 \mathrm{~mm}$ (4 in) \\
\hline & SP 8 & SP 8 & & $203.2 \mathrm{~mm}(8 \mathrm{in})$ \\
\hline & SP 12 & SP 12 & \multirow{3}{*}{ Double sinusoidal pulses } & $304.8 \mathrm{~mm}$ (12 in) \\
\hline & None & SP 16 & & $406.4 \mathrm{~mm}$ (16 in) \\
\hline & None & SP 20 & & $508.0 \mathrm{~mm}(20 \mathrm{in})$ \\
\hline
\end{tabular}


Table 3. Drift and rotational limit states $[54,55]$.

\begin{tabular}{|c|c|c|c|}
\hline \multirow{2}{*}{ Limit states } & \multirow{2}{*}{ Drift limits (\%) } & \multicolumn{2}{|c|}{ Rotational limits (rad) } \\
\hline & & Column & Beam \\
\hline $\begin{array}{l}\text { Immediate } \\
\text { occupancy (IO) }\end{array}$ & $\leq 1.0$ & $\leq 0.005$ & $\leq 0.005$ \\
\hline Life safety (LS) & $\leq 2.0$ & $\leq 0.027$ & $\leq 0.020$ \\
\hline $\begin{array}{l}\text { Collapse } \\
\text { prevention }(\mathrm{CP})\end{array}$ & $\leq 4.0$ & $\leq 0.034$ & $\leq 0.030$ \\
\hline
\end{tabular}


Figure 1

(a)

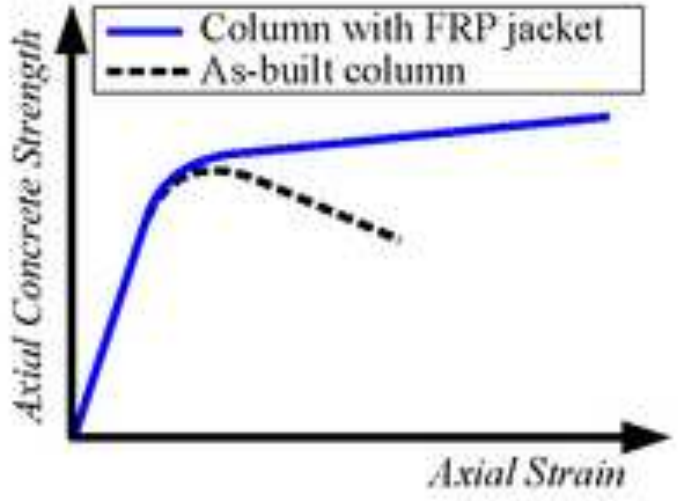

(b)

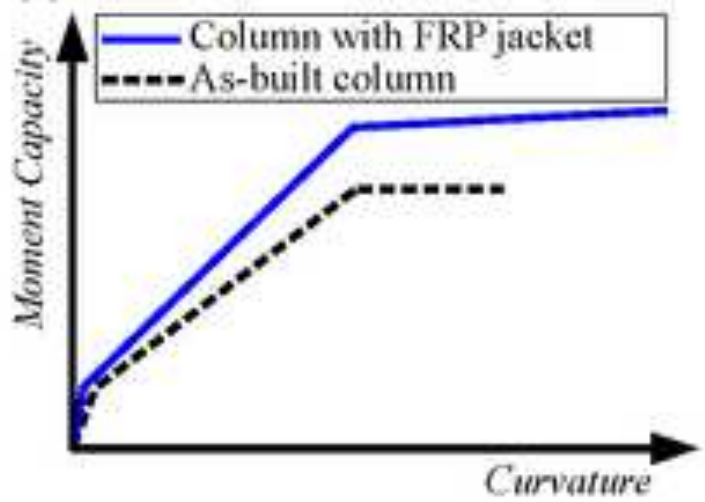




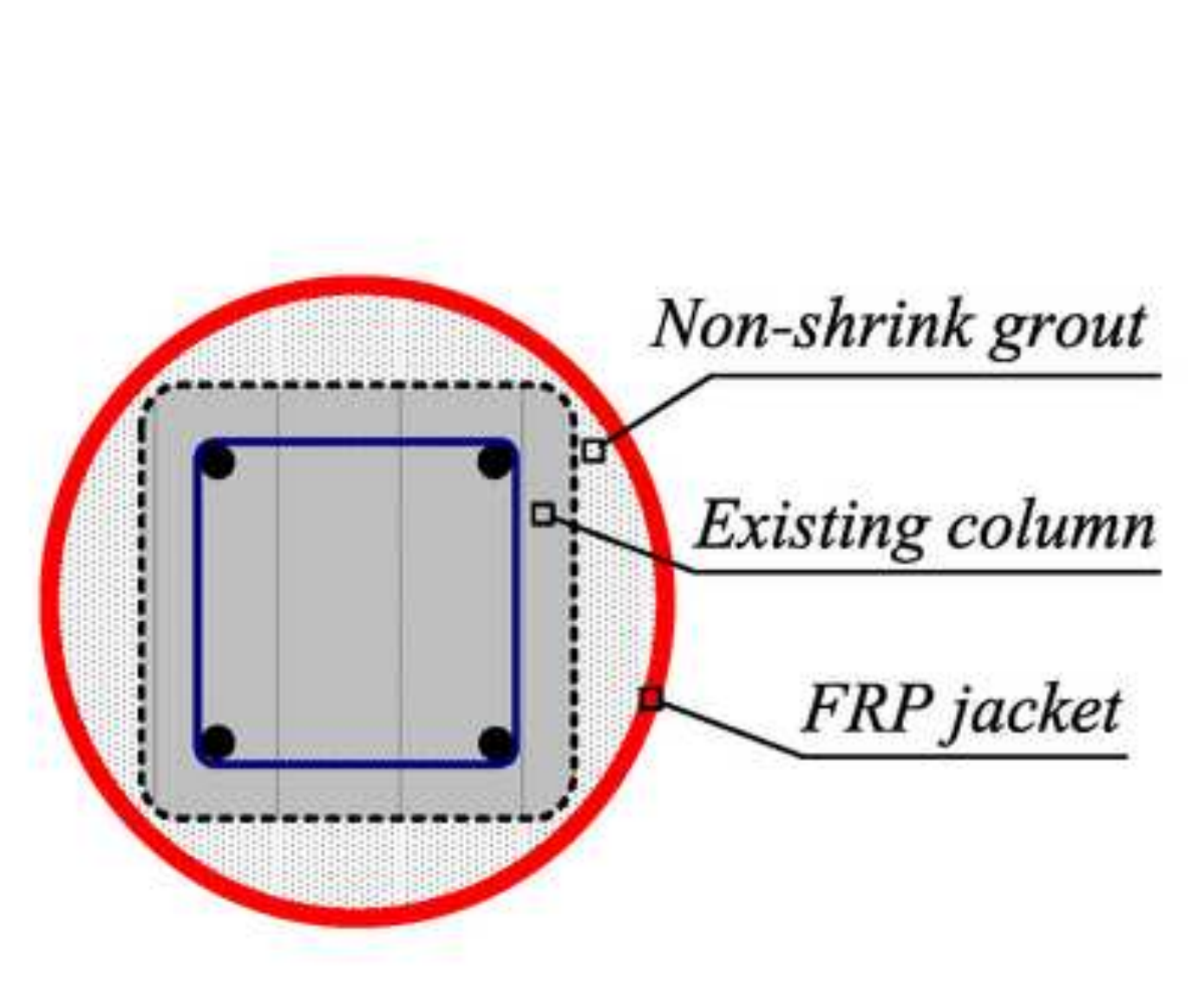

Figure 2

2

(1)

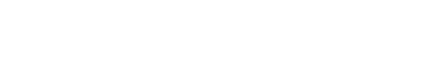

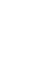

更
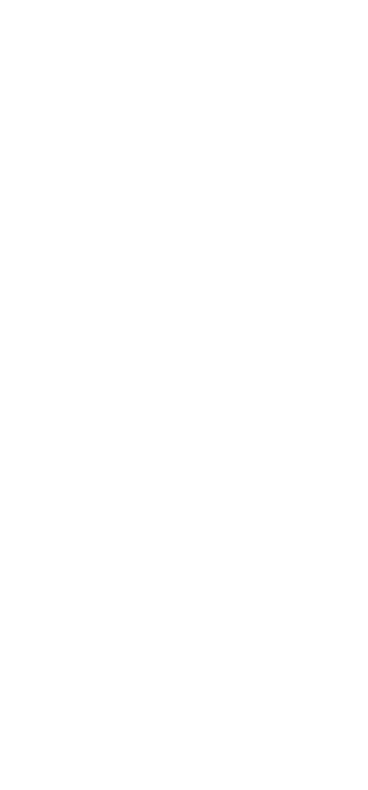

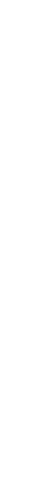

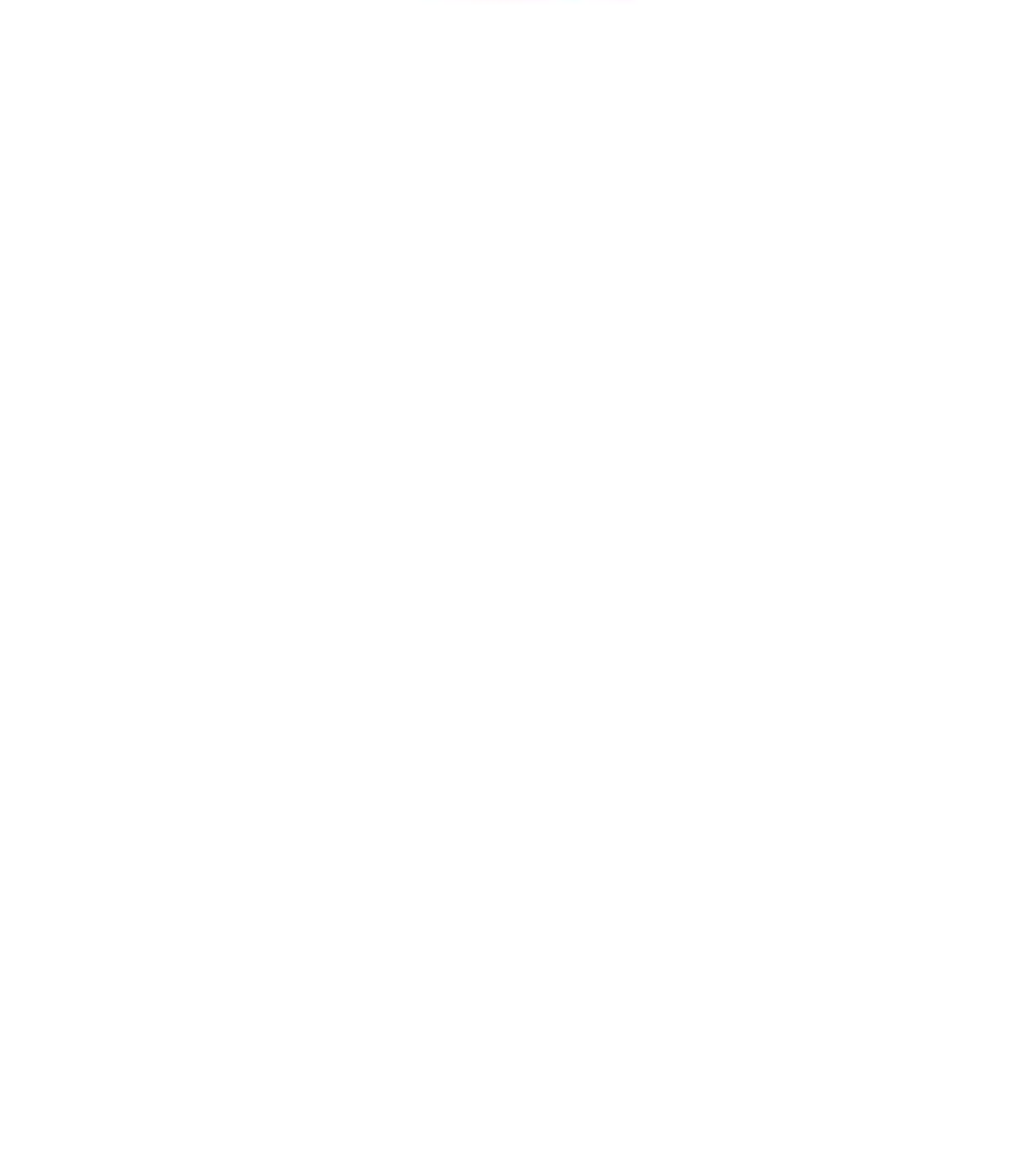




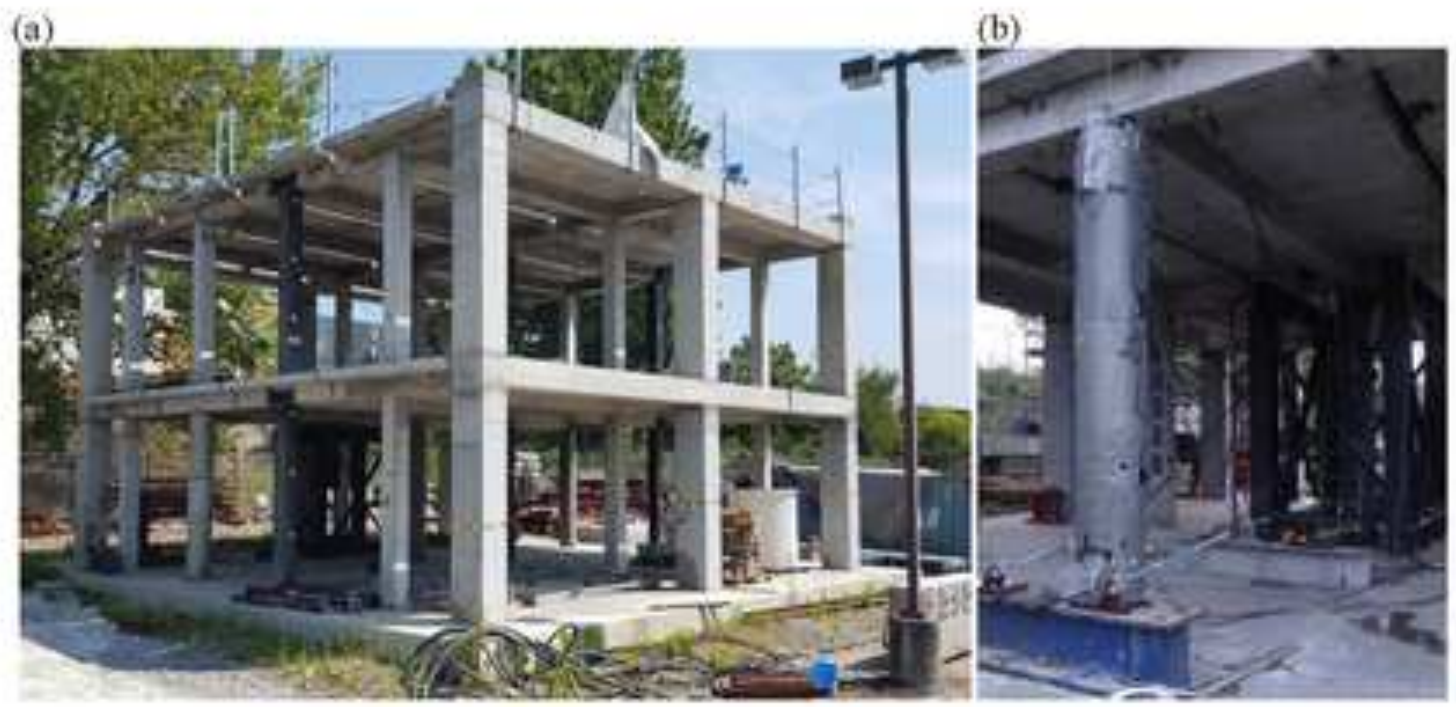




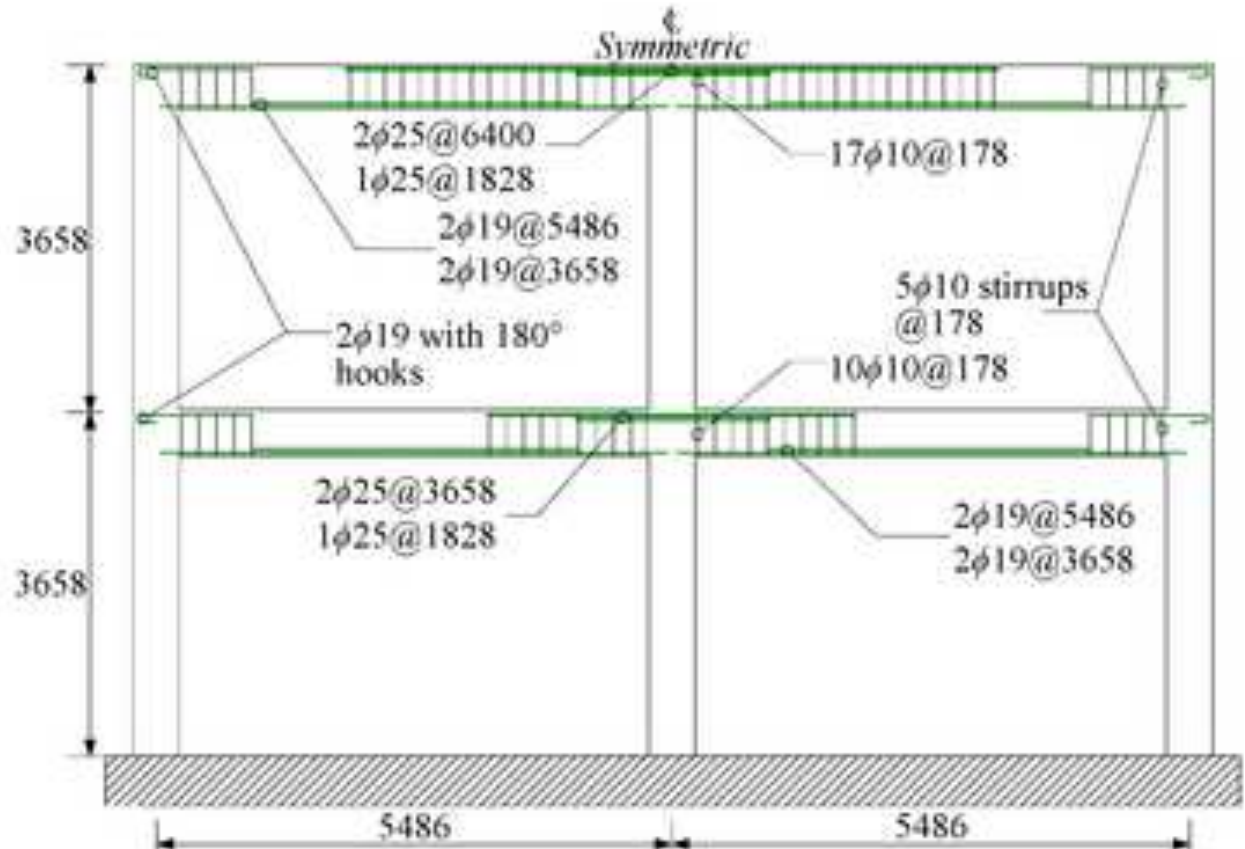

In-plane beam details

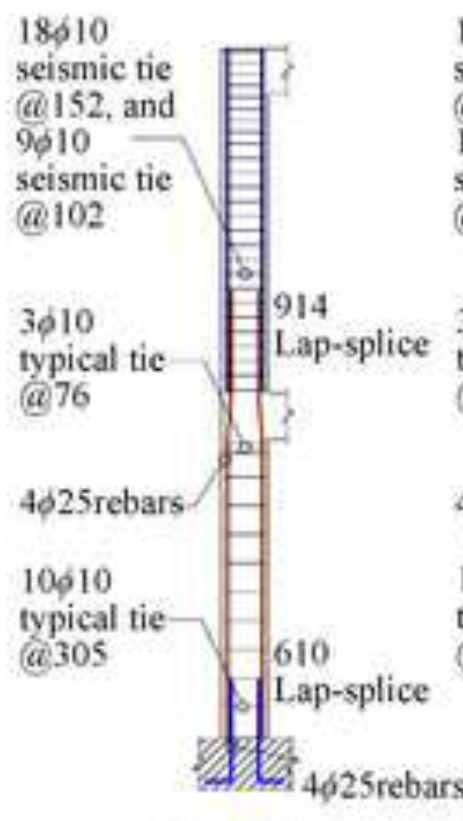

Exterior column details

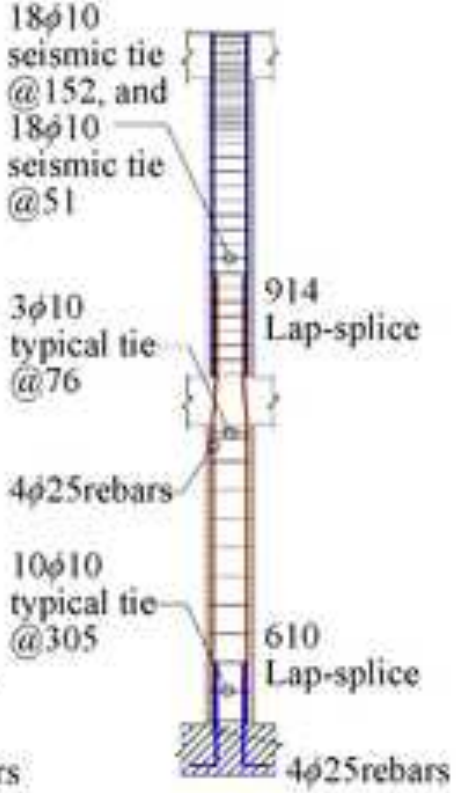

Interior column details 

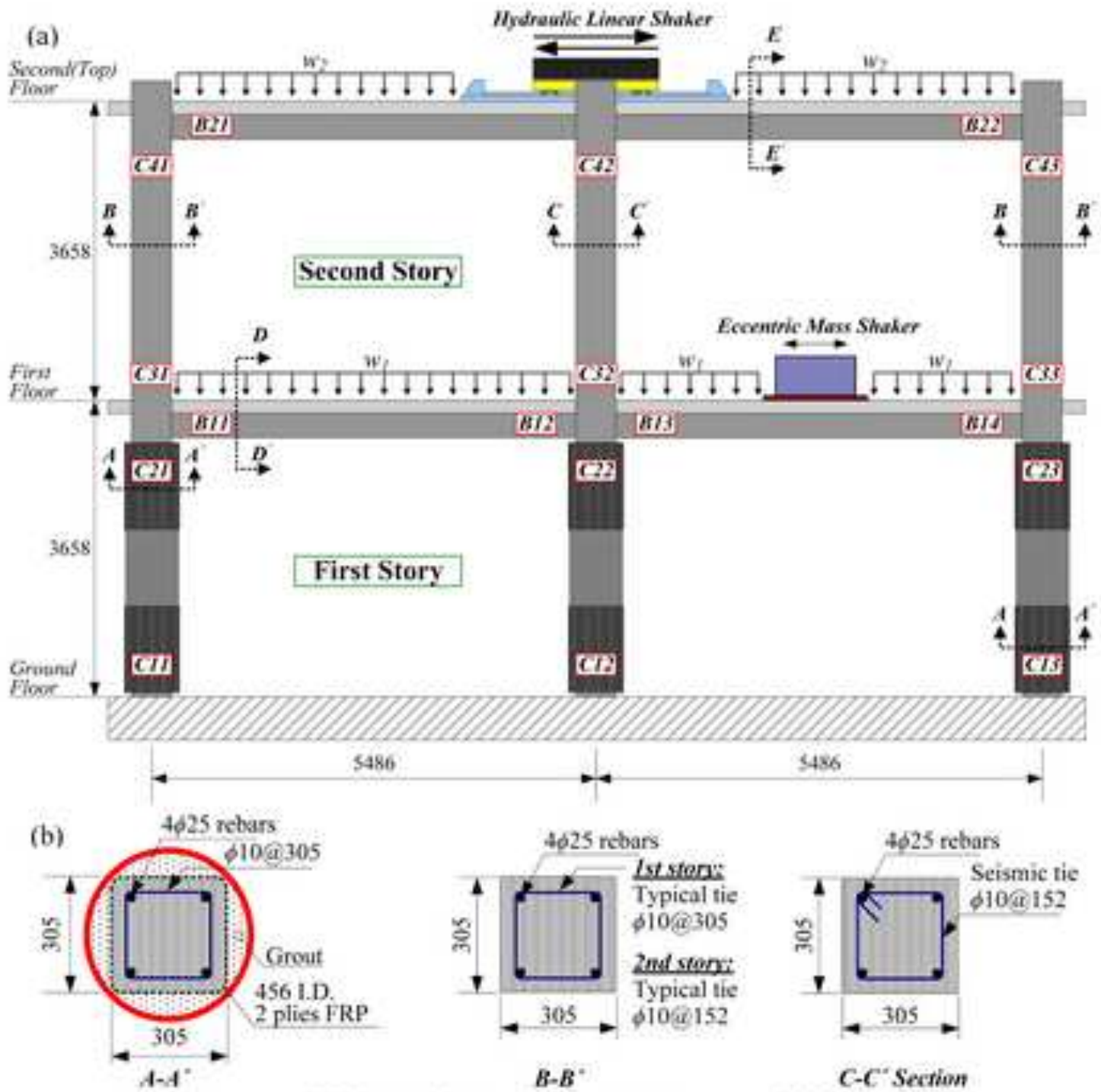

$2 \phi 19$ rebars $\quad \phi 10$ Hanger stimup

$B-B^{*}$

C-C'Section
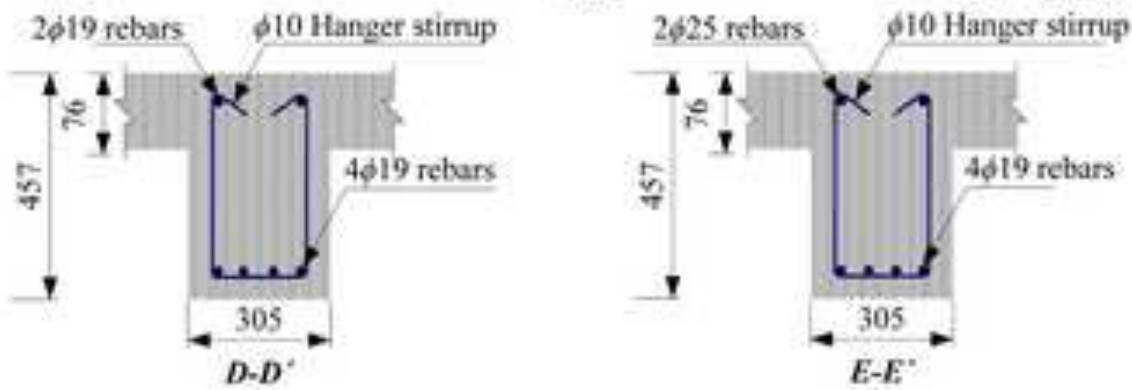

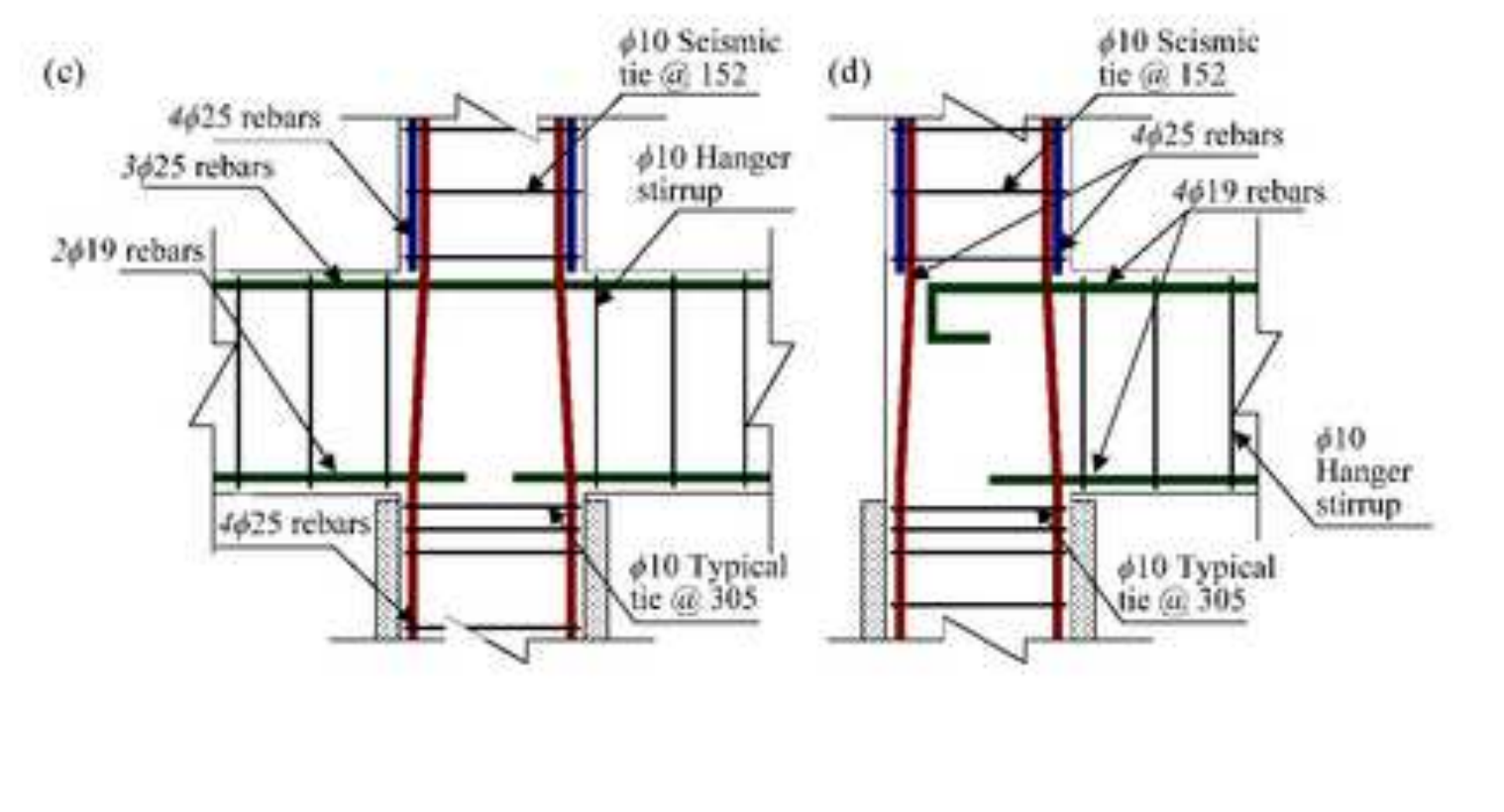
(c)

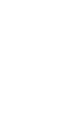

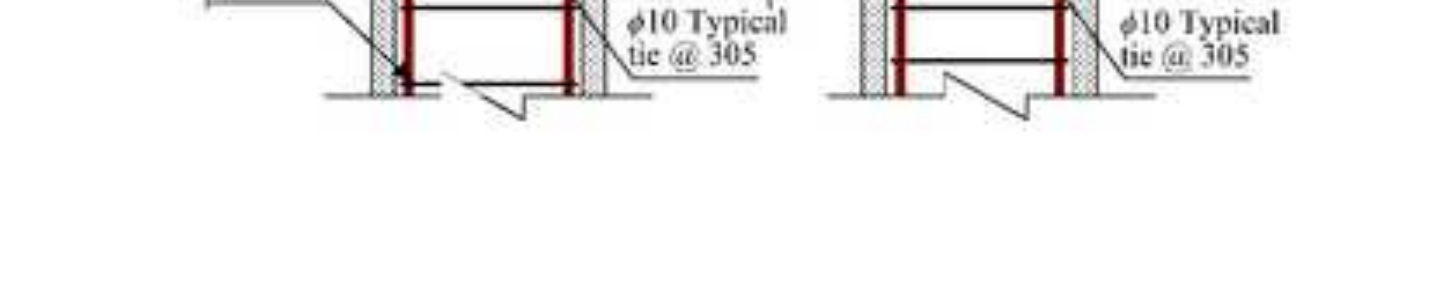


(a)

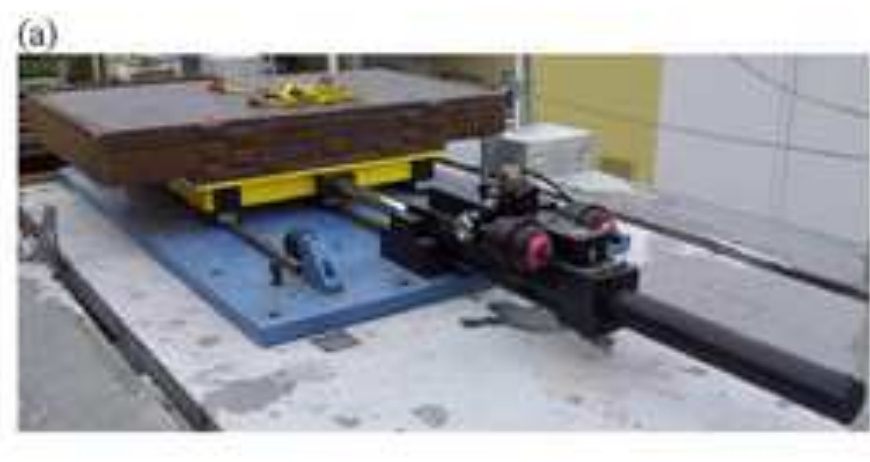

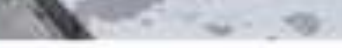

(b)

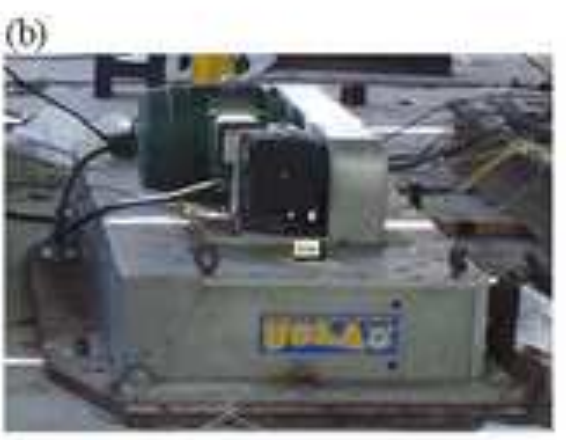

Figure 6 
(a)

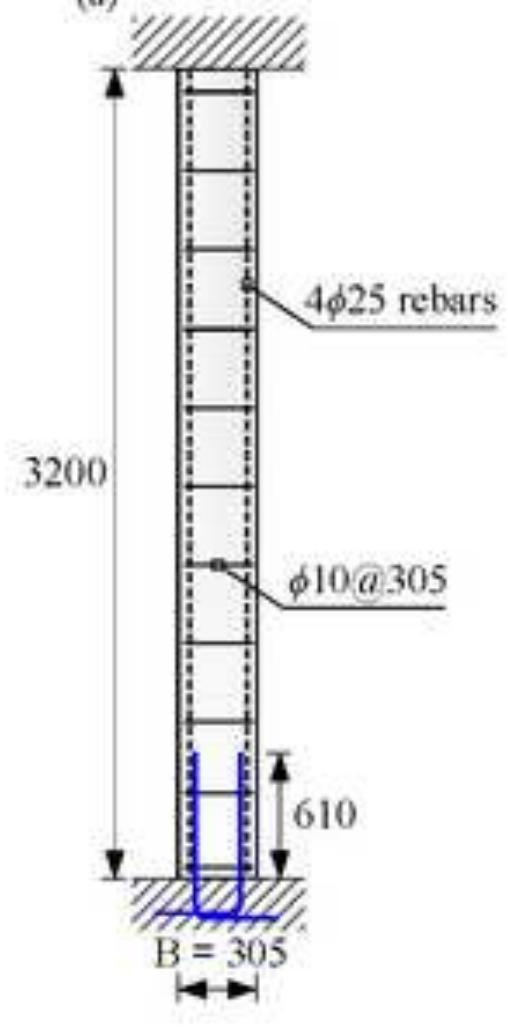

(a) (b)

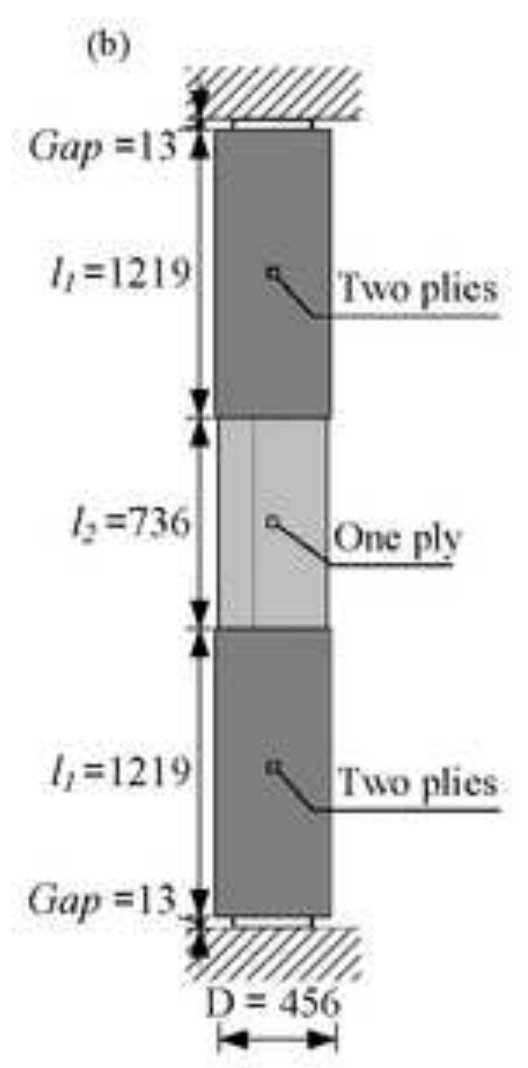

Figure 7 


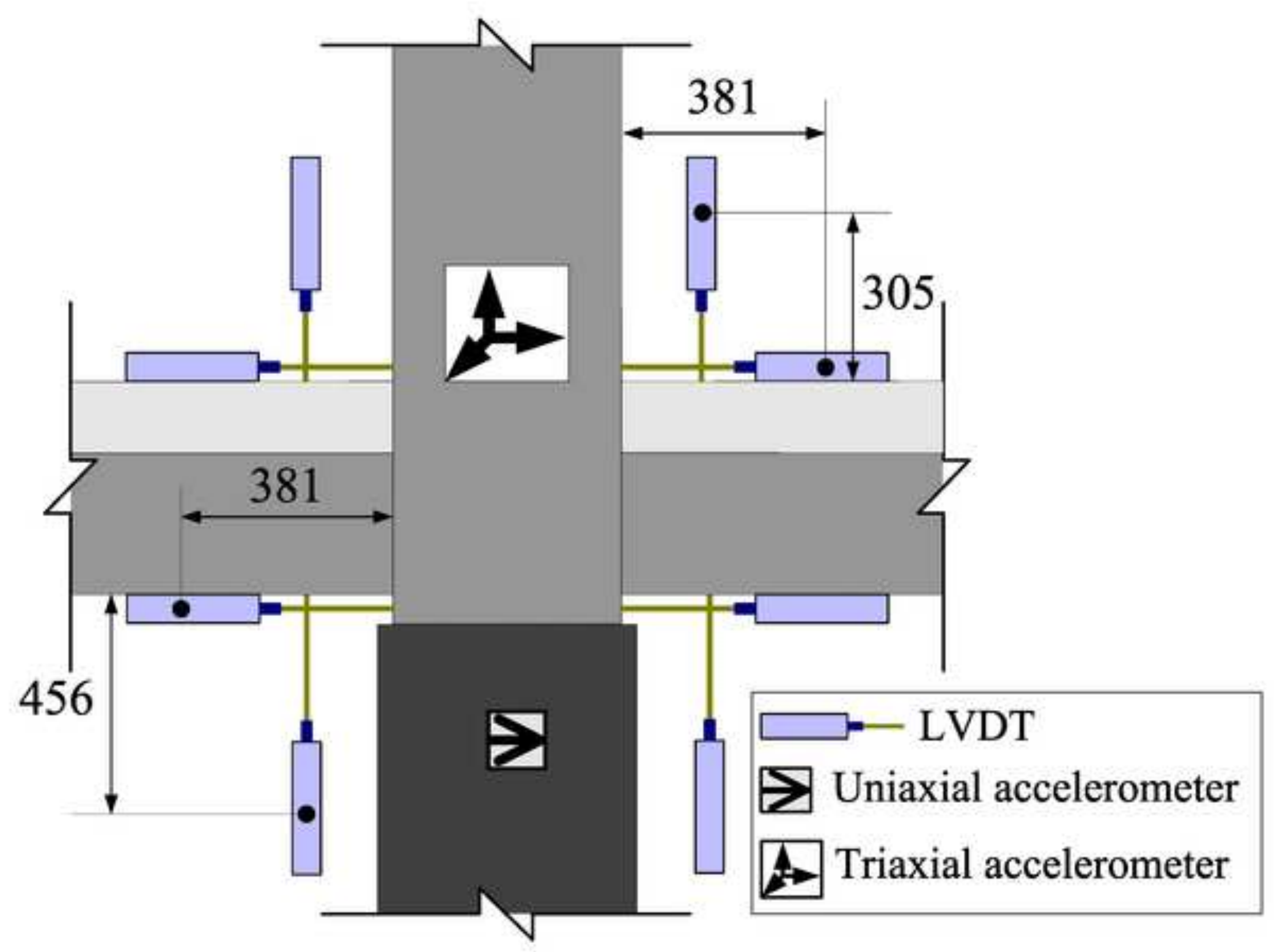


Figure 9

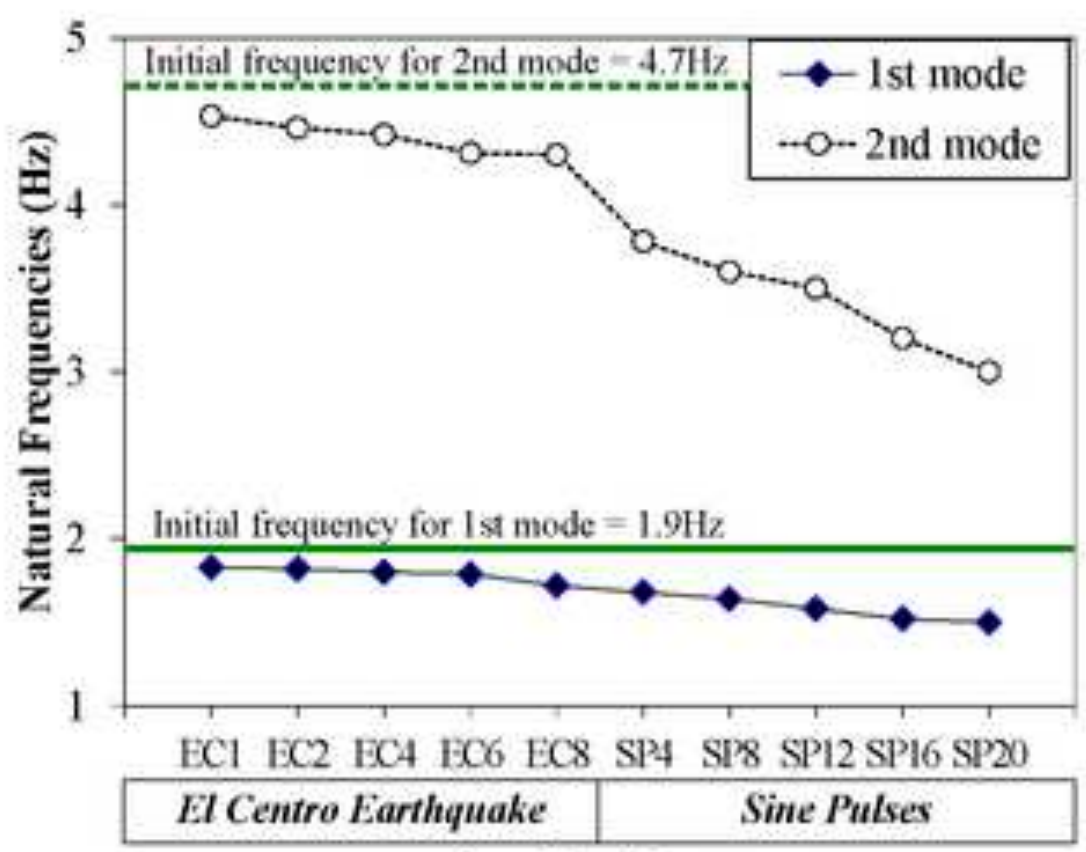
\begin{tabular}{r|r} 
El Centro Earthquake & Sine \\
\multicolumn{2}{c|}{ Loading Sequence }
\end{tabular} \begin{tabular}{r|r} 
El Centro Earthquake & Sime \\
\multicolumn{2}{c|}{ Loading Sequence }
\end{tabular} 


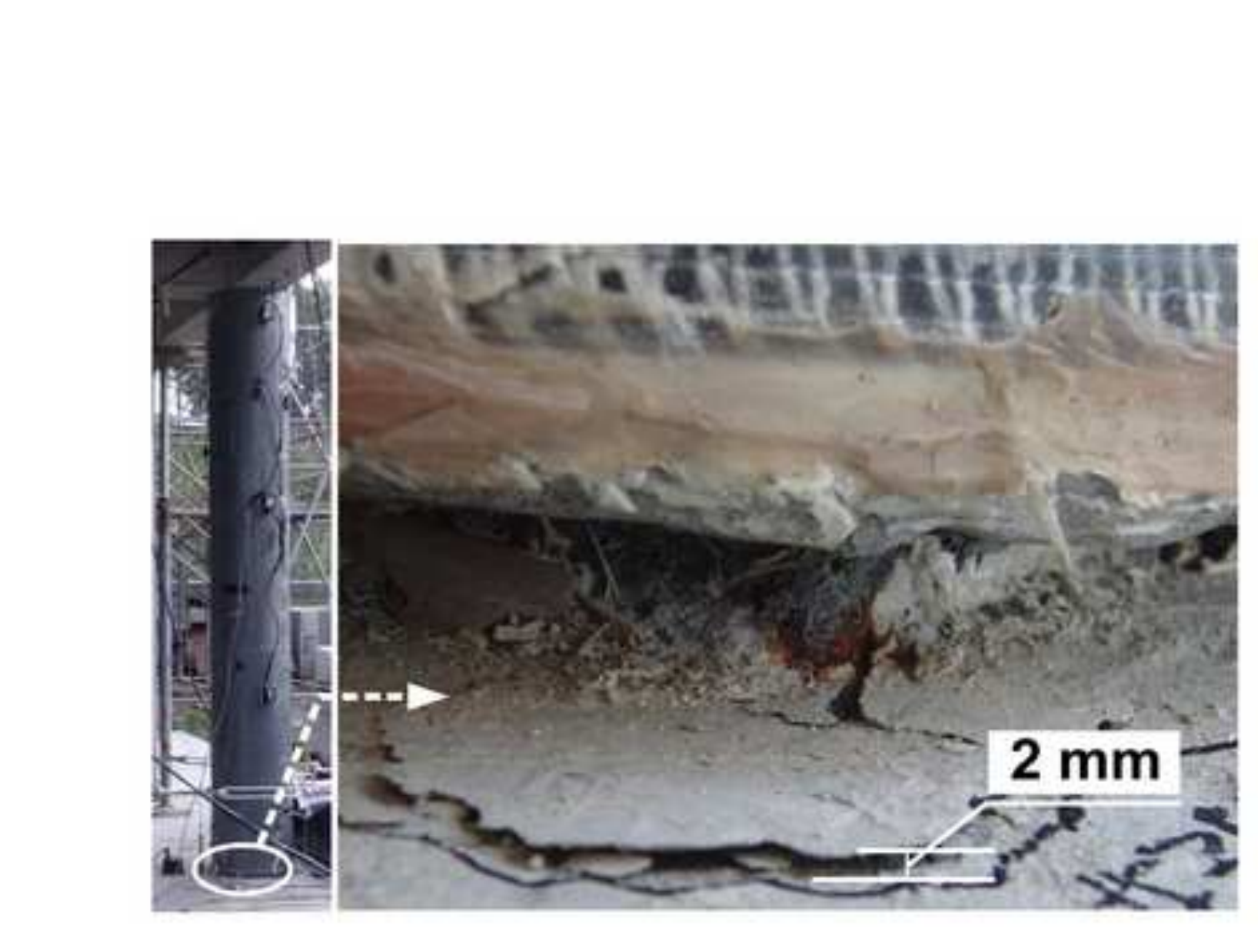

Figure 10

Fure 10

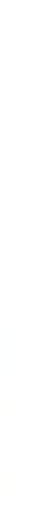

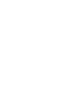

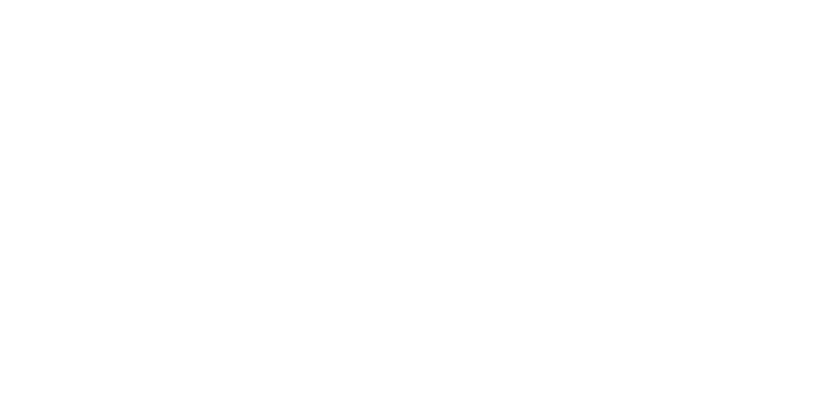



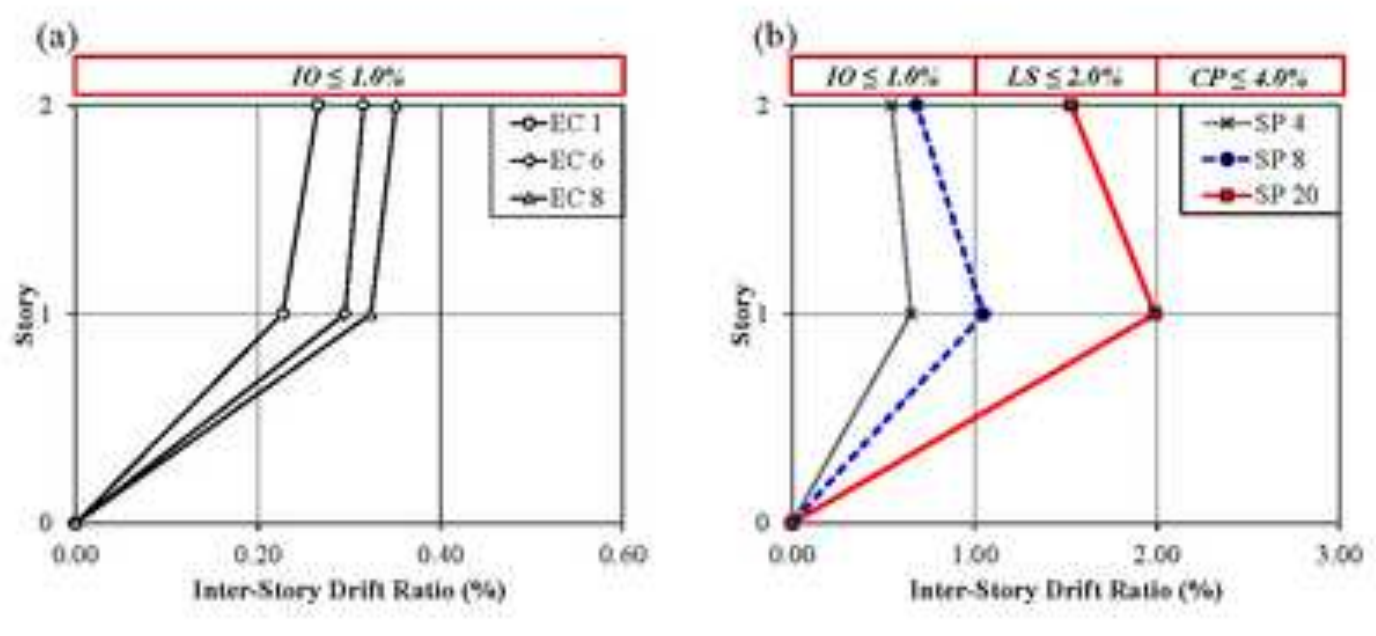

Figure 11

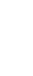


(b)

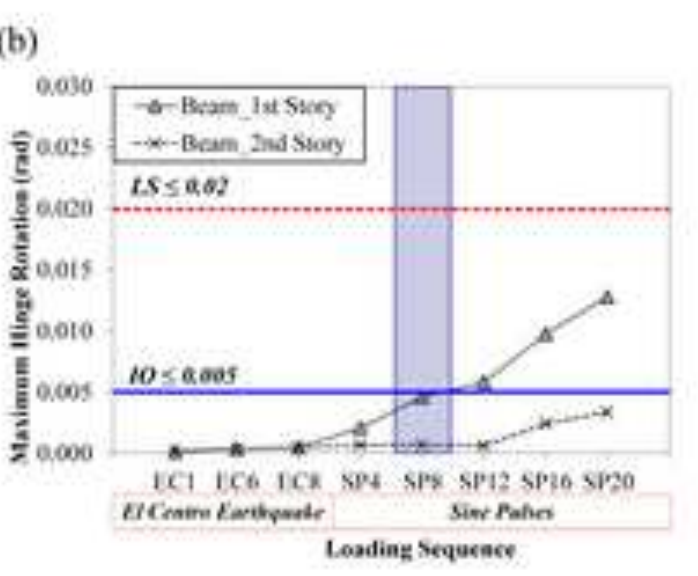

(a)

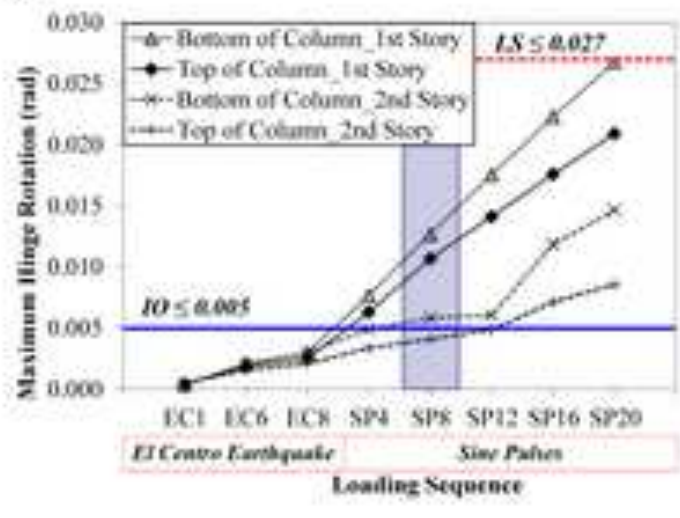

)

\section{Figure 12}

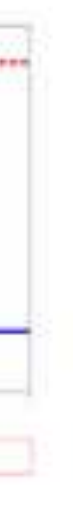




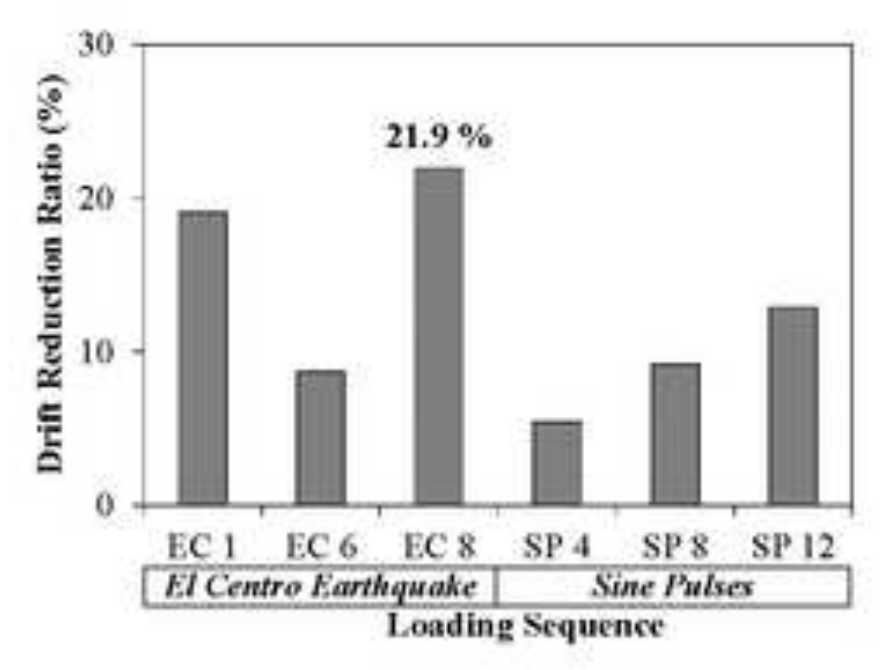

Figure 13

3




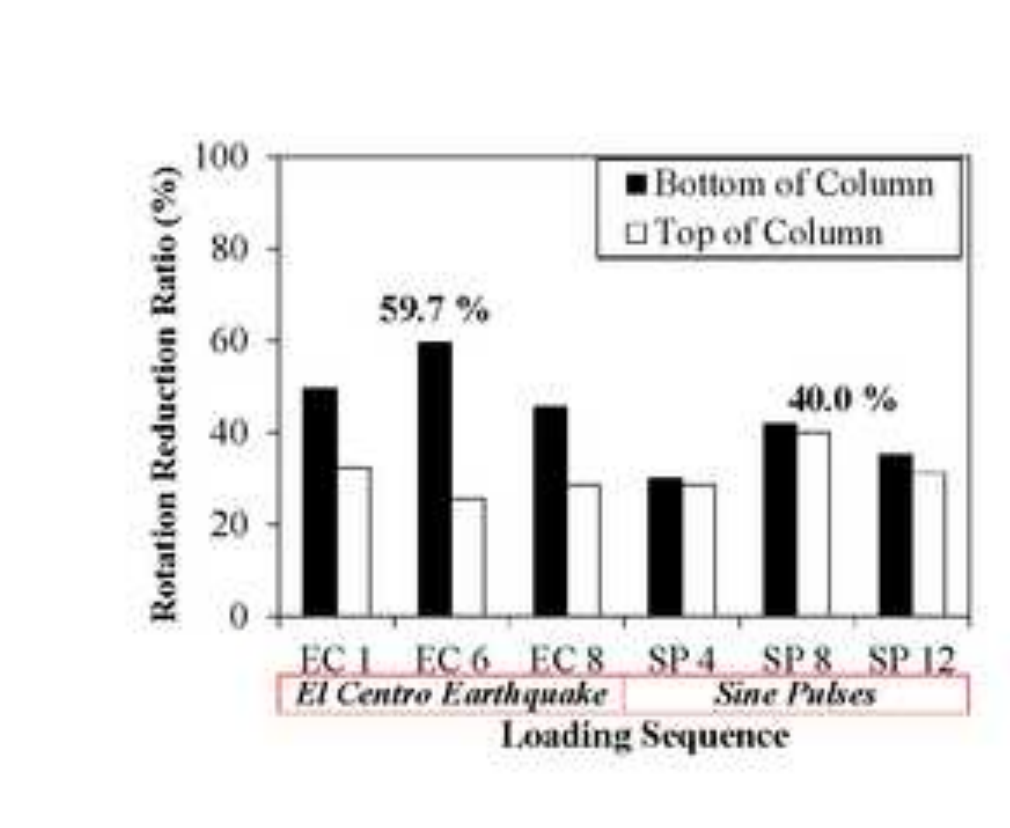

Figure 14

Loading Sequence

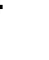

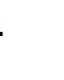
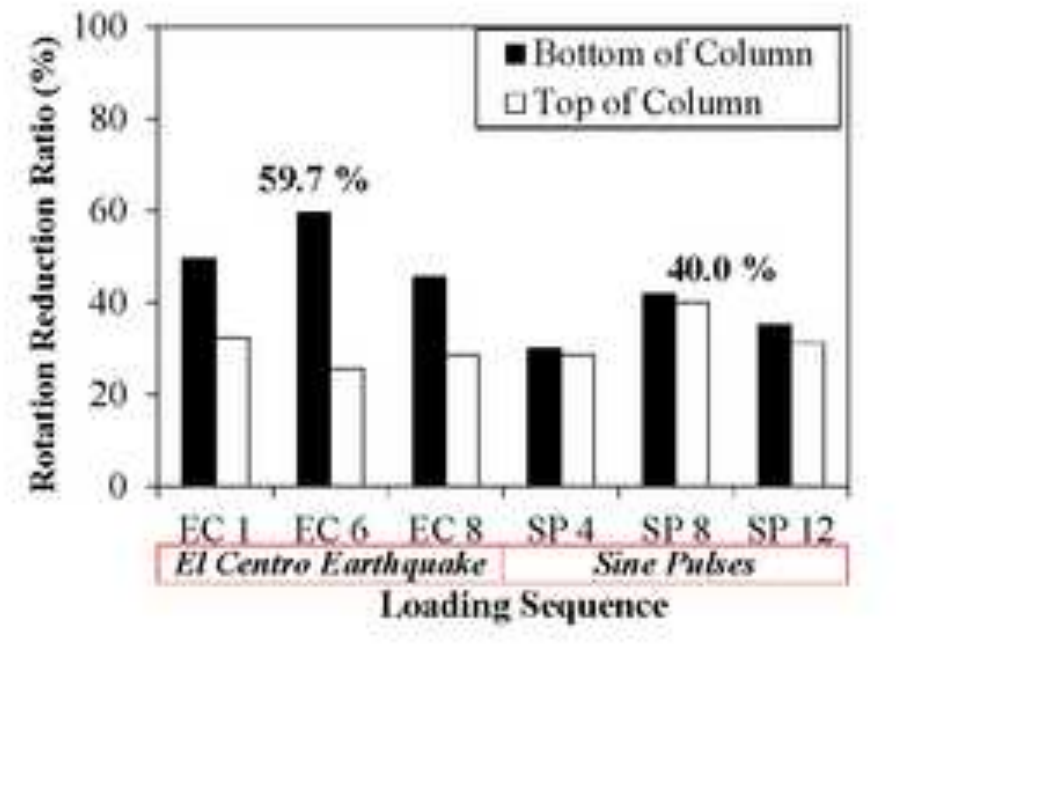
.

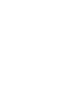
(1)
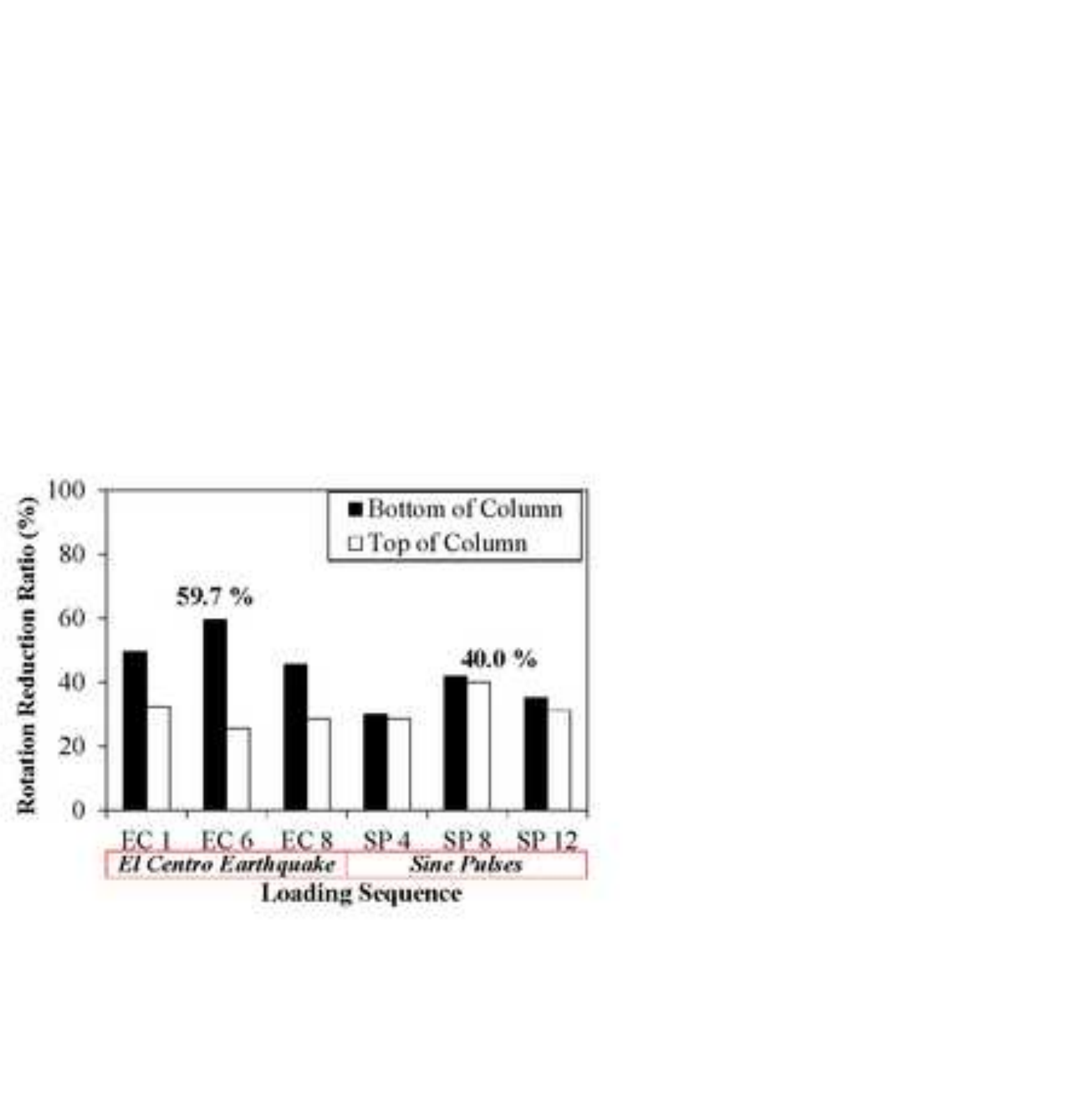

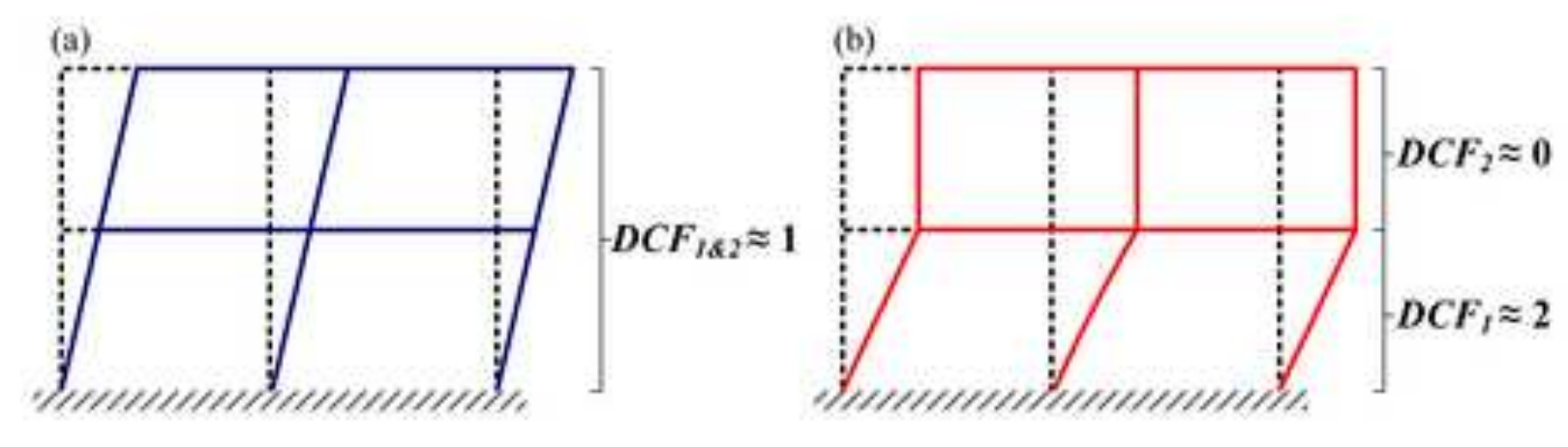

Figure 15

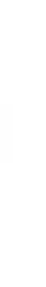


